\title{
Prograde and retrograde diagenetic and metamorphic evolution in metapelitic rocks of Sierra Espuña (Spain)
}

\author{
I. ABAD ${ }^{1}$, F. NIETO ${ }^{2}$, D. R. PEACOR ${ }^{3}$ AND N. VELILLA ${ }^{4}$ \\ ${ }^{1}$ Departamento de Geología, Universidad de Jaén, 23071 Jaén, Spain, ${ }^{2}$ Instituto Andaluz de Ciencias de la Tierra y \\ Departamento de Mineralogía y Petrología, Universidad de Granada, 18002 Granada, Spain, ${ }^{3}$ Department of \\ Geological Sciences, University of Michigan, Ann Arbor, MI 48109-1063, USA, and ${ }^{4}$ Departamento de Mineralogía y \\ Petrología, Universidad de Granada, 18002 Granada, Spain
}

(Received 2 April 2002; revised 22 July 2002)

\begin{abstract}
An unusually complete sequence of pelitic rocks ranging from diagenetic to greenschist-facies metamorphic grades occurs in southern Sierra Espuña, Spain. Prograde and retrograde reactions have been studied by X-ray diffraction and electron microscopy (SEM, TEM and AEM). The prograde reaction series, with reactions facilitated by tectonic stress, includes: (1) R4 interstratified illite-smectite in the diagenetic Malaguide Complex that preserves the variable orientation of original smectite packets, and has $1 M \mathrm{~d}$ polytypism; (2) chemically heterogeneous illite and $\mathrm{Na}-\mathrm{K}$ dioctahedral white micas that progressively evolve toward chemical and textural equilibrium in the anchizonal Intermediate Units; and (3) thick, defect-free packets of phengite, paragonite and clinochlore which have a typical metamorphic texture, in the Alpujarride Complex. Two superimposed retrograde episodes produced: (a) sudoite at near-peak metamorphic conditions and (b) dioctahedral smectite during low-temperature retrograde diagenesis.
\end{abstract}

KEYwORDs: XRD, illite crystallinity, electron microscopy, very low-grade metamorphism, sudoite, micas.

The full sequence from earliest diagenesis to greenschist-facies metamorphism has not yet been observed in a single continuous sequence of metapelitic zones. It is nevertheless possible to distinguish two kinds of diagenetic to low-grade metamorphic sequences: (a) those affected by passive sedimentation, as in Gulf Coast sediments (e.g. Ahn \& Peacor, 1986) or the BasqueCantabrian Basin (Nieto et al., 1996); and (b) those subject to tectonic stress, e.g. the Welsh Sedimentary Basin (Merriman \& Roberts, 1985) and the metasediments of the Gaspé Peninsula, Quebec (Jiang et al., 1994). Studies of a variety of sequences are essential in order to understand the

* E-mail: fnieto@ugr.es

DOI: $10.1180 / 0009855033810074$ significance of factors such as initial sediment lithology and subsequent tectonic history. In rocks of the Sierra Espuña area, Spain, low-grade metamorphism has been triggered by tectonic activity. The rocks of this area include an unusually large range of diagenesis in the Maláguide Complex, from a very low-temperature environment to greenschist-facies metamorphism in the Alpujárride Complex, with a clockwise PTt evolution described by Azañón \& Crespo-Blanc (2000). Only the very lowest-grade diagenesis, for which smectite-rich clay minerals are diagnostic, is not represented. As such, nearly complete lowgrade metamorphic sequences are rare, making the Espuña area a very interesting region for studying a complete range of evolution from diagenesis through to epizonal metamorphism. Thus, it is possible to try to establish the prograde and 
retrograde processes that determine typical lowgrade mineral assemblages and their textural characteristics.

As mineral reactions may not be complete in low-grade metasediments, the assemblages are in disequilibrium and the recognition of genetic relations between the different phases and the identification of paragenetic associations is a major problem. The very fine-grained texture of these rocks makes it difficult to examine them even by scanning electron microscopy (SEM), using backscattered electron (BSE) imaging, and so a transmission electron microscope (TEM) study was used to understand the textural relationships and chemistry of phyllosilicates in them at lattice scale. The aim of this research is to advance our knowledge of low-grade metamorphic processes in order to characterize prograde events and to differentiate them from retrograde overprints. To do so, a detailed study of the rocks must be carried out. The sequence of the Espuña area has been the subject of a TEM study of the regional retrograde alteration of chlorite to smectite (Nieto et al., 1994) and therefore is especially suitable for studying prograde-retrograde transformations in phyllosilicates.

\section{GEOLOGICAL SETTING AND MATERIALS}

Sierra Espuña is located in the Internal Zones of the Betic Cordillera (southern Spain), the westernmost European Alpine chain. It has been the subject of detailed studies of cartographic and stratigraphic relations (Paquet, 1969). Metamorphic relations were studied by Mäkel \& Rondeel (1979), and structural aspects were investigated by Mäkel (1981, 1985), Lonergan (1991) and Lonergan et al. (1994). The most recent studies of Sierra Espuña focused on stratigraphy (Martín-Martín \& MartínAlgarra, 1997) and redefinition of the tectonic units (Sanz de Galdeano et al., 2001). The nomenclature used in this work is based on that used in the latter reference.

Three large tectonic complexes have been distinguished in the Internal Zones of the Betic Cordillera, tectonically superimposed in the order (from bottom to top) Nevado-Filábride, Alpujárride and Maláguide Complexes. Each complex comprises multiple, superimposed tectonic units. Sanz de Galdeano et al. (2001) concluded that there are five imbricated tectonic units in the southern part of Sierra Espuña (Fig. 1). The upper one belongs to the Maláguide Complex (Morrón de Totana), below which there are three Intermediate Units (La Santa, Yéchar and Jaboneros) with transitional stratigraphic and metamorphic features and an intermediate tectonic position between the Maláguide and Alpujárride Complexes. The lowest tectonic unit is Los Molinos, an Alpujárride Unit. According to Mäkel \& Rondeel (1979), the Maláguide and Intermediate Units were affected only by very low-grade metamorphism or by diagenesis, whereas the Alpujárride Unit was affected by greenschist-facies metamorphism.

Thirty nine samples were collected from outcrops, taking care that they were free of surface alteration effects. The Los Molinos, Yéchar, La Santa and Morrón de Totana units each include two formations (Mäkel \& Rondeel, 1979): (a) a Permian-Triassic formation, composed of conglomerates, sandstones and red pelitic rocks; and (b) an Upper Triassic carbonate formation, in which dolomitic rocks predominate. Only detrital non-carbonate rocks were sampled throughout the different units, except Jaboneros, the outcrops of which are small and beyond the limits of the studied section. In general, the rocks are red and green metapelites intercalated with thick indurated sandstone beds. The Los Molinos Unit is a grey phyllite and rocks at the Yéchar Unit are brown greywackes with variable proportions of matrix, consisting in part of phyllosilicates cemented by carbonates. Quartz grains are abundant. The proportions of clay minerals are relatively small and these samples are therefore considered to be semipelitic rocks. The La Santa Unit rocks, tectonically superimposed on the Yéchar Unit, are red and green metapelites. The stratigraphic succession is very similar to that of the Yéchar Unit. In the upper unit, Morrón de Totana, the stratigraphic sequence is complicated by lateral facies changes (carbonate indentations). The sampled horizons are red-orange pelites with intercalated conglomerates and carbonates.

\section{ANALYTICAL METHODS}

Samples were studied by optical microscopy and $\mathrm{X}$-ray diffraction (XRD) in order to determine the overall trends in mineral assemblages and grade. The matrix materials are too fine grained to be resolved even by BSE imaging except for samples with the highest metamorphic grade. Therefore, 


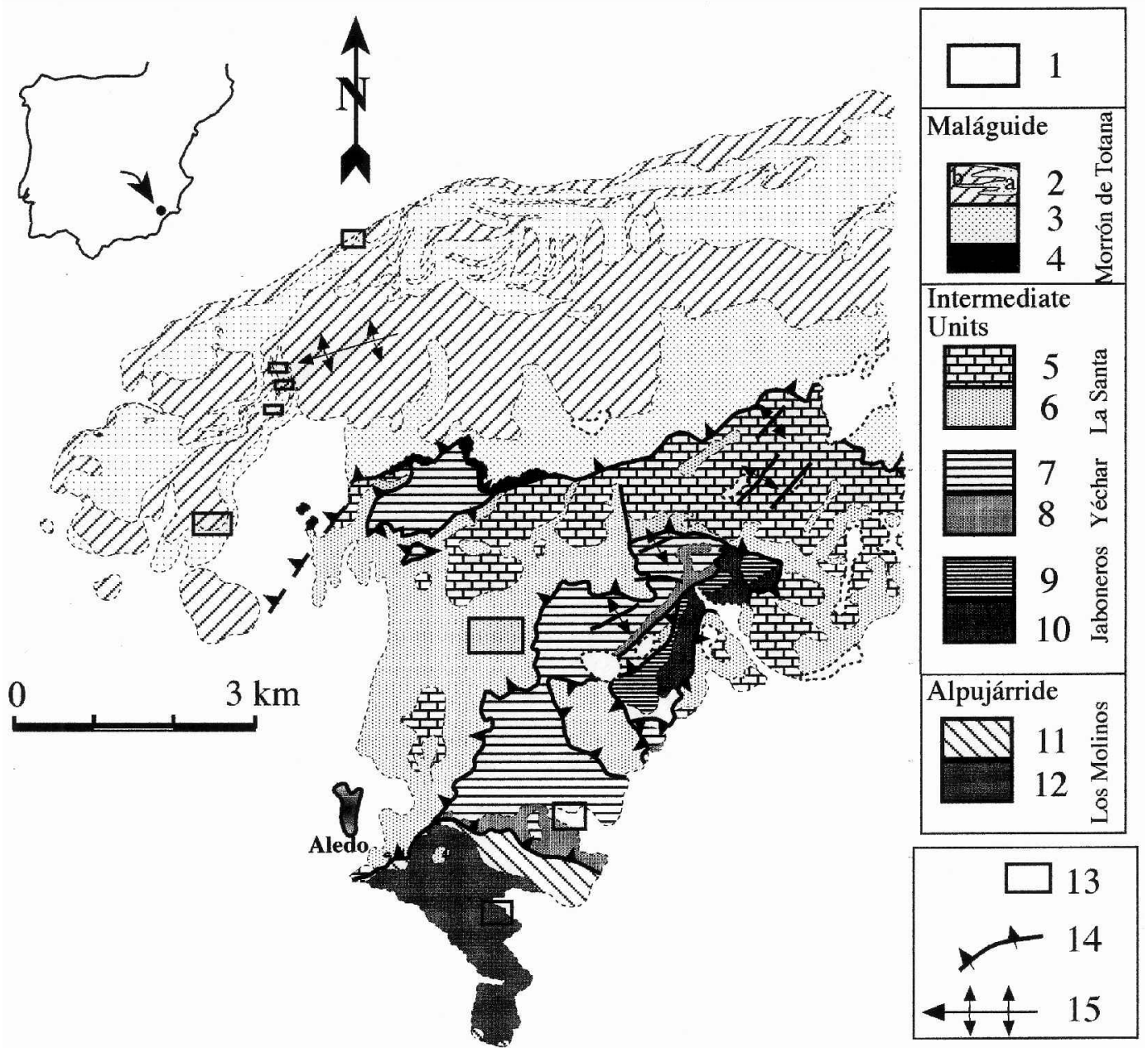

FIG. 1. Geological map of Sierra Espuña (based on Sanz de Galdeano et al., 2001). (1) Tertiary and Quaternary terrains; (2) (a) pelites and sandstones, (b) carbonate rocks; (3) pelites, sandstones and conglomerates; (4) pelites and greywackes; (5), (7), (9) and (11) carbonate rocks; (6) and (8) pelites and sandstones; (10) and (12) phyllites and quartzites; (13) sample locations; (14) thrust-nappe; (15) anticline. The tectonostratigraphic column giving the highest and lowest units in a thrust stack is shown on the right. All these strata are Triassic except for (4), which consists of Upper Palaeozoic sedimentary rocks.

HRTEM was required to characterize the textural relationships between the minerals, especially the phyllosilicates.

\section{$X$-ray diffraction}

Unaltered samples were obtained from well below the outcrop surface and away from joints, to minimize alteration by weathering. Samples were washed and, after coarse crushing, homogeneous rock chips were used for preparation of samples for
XRD. Whole-rock samples and clay fractions $(<2 \mu \mathrm{m})$ were studied using a Philips PW 1710 powder diffractometer with $\mathrm{Cu}-K \alpha$ radiation, graphite monochromator and automatic divergence slit at the Departamento de Mineralogía y Petrología of the Universidad de Granada. The $<2 \mu \mathrm{m}$ fractions were separated by repeated extraction of supernatant liquid subsequent to settling. Oriented aggregates were prepared by sedimentation on glass slides. Ethylene-glycol (EG) treatment was carried out on some samples 
to corroborate the identification of smectite and/or illite-smectite mixed-layers. Preparation of samples and experimental conditions for illite "crystallinity" (IC) measurements were carried out according to IGCP 294 IC Working Group recommendations (Kisch, 1991). Our IC measurements $(y)$ were transformed into C.I.S. values $(x)$ according to the equation $y=0.674 x+0.052(r=0.999)$, obtained in our laboratory using the international standards of Warr \& Rice (1994). The IC values were measured for the $<2 \mu \mathrm{m}$ fractions, $<2 \mu \mathrm{m}$ EG-treated fractions and for the bulk-rock samples. The $b$ cell parameters of micas and chlorites were obtained from the (060) peaks measured on slices of rock cut normal to the sample foliation. For all spacing measurements, quartz from the sample itself was used as internal standard.

\section{Electron microscopy}

Following the XRD and optical studies, seven representative samples of the different tectonostratigraphic levels were selected for electron microscopy study on the basis of the IC values and the mineral assemblages. Carbon-coated slices were examined by SEM, using back-scattered electron (BSE) imaging and energy-dispersive X-ray (EDX) analysis in order to obtain textural and chemical data. These observations were carried out using a Zeiss DSM 950 SEM, equipped with an X-ray Link Analytical QX-20 energy-dispersive X-ray system (EDX) at the Centro de Instrumentación Científica (C.I.C), Granada. An accelerating voltage of $20 \mathrm{kV}$, with a beam current of $1-2 \mathrm{nA}$ and counting time of $100 \mathrm{~s}$ were used to analyse the phyllosilicates by SEM, using both natural and synthetic standards: albite $(\mathrm{Na})$, periclase $(\mathrm{Mg})$, wollastonite $(\mathrm{Si}$ and $\mathrm{Ca})$, and orthoclase $(\mathrm{K})$, and synthetic $\mathrm{Al}_{2} \mathrm{O}_{3}(\mathrm{Al})$, $\mathrm{Fe}_{2} \mathrm{O}_{3}(\mathrm{Fe})$ and $\mathrm{MnTiO}_{3}$ ( $\mathrm{Ti}$ and $\mathrm{Mn}$ ). Ion-milled and carbon-coated specimens were studied by TEM with two microscopes: (1) a Philips CM12 scanning transmission electron microscope (STEM), operated at an accelerating voltage of $120 \mathrm{kV}$ and beam current of $\sim 10 \mu \mathrm{A}$, equipped with a Kevex Quantum EDX system (University of Michigan), and (2) a Philips CM20 (STEM) equipped with an EDAX solid-state EDX detector, operated at $200 \mathrm{kV}$, with a $\mathrm{LaB}_{6}$ filament (C.I.C.). Latticefringe images of phyllosilicates were obtained using (001) reflections. Records of TEM data included 144 lattice-fringe images and 94 selected area electron diffraction (SAED) patterns.
The EDX spectra of ion-milled samples were obtained using a raster of $1000 \times 200 \AA$ in scanning mode to minimize alkali diffusion and volatilization with the long axis oriented parallel to the length of phyllosilicate packets. Analytical electron microscopy (AEM) quantitative chemical analyses were obtained from spectra using ion-milled standards of muscovite, albite, clinochlore, fayalite and sphene to derive $\mathrm{k}$-values, following the procedure of Jiang et al. (1990). The AEM analyses were also obtained from powders dispersed over holey $\mathrm{C}$-coated formvar $\mathrm{Cu}$ grids, after first verifying the monomineralic character of each grain with a SAED pattern. Such analyses permit larger areas to be used in scanning transmission mode (STEM) (area of $1 \mu \mathrm{m} \times 1 \mu \mathrm{m}$ ) with greater accuracy, because elements, especially alkalis, cannot diffuse away from the area analysed. Shorter counting times (30 s) were used for K, to further minimize loss (Nieto et al. 1996). Albite, biotite, spessartine, muscovite, olivine, titanite, $\mathrm{MnS}$ and $\mathrm{CaS}$ were used as standards to derive k-factors for the transformation of intensity ratios to concentration ratios following the procedures of Cliff \& Lorimer (1975).

The structural formulae of micas were calculated on the basis of 22 negative charges $\mathrm{O}_{10}(\mathrm{OH})_{2}$. Although these analytical techniques cannot distinguish between $\mathrm{Fe}^{3+}$ and $\mathrm{Fe}^{2+}$, Guidotti et al. (1994) showed that the opaque-mineral assemblage (hematite in these samples) can be used to estimate the $\mathrm{Fe}^{3+} / \mathrm{Fe}^{2+}$ ratio in muscovite. Even in low redoxpotential parageneses, $\sim 50 \%$ of the $\mathrm{Fe}$ in muscovite is $\mathrm{Fe}^{3+}$, and values close to $85 \%$ can be reached in less reducing environments. Therefore, in the calculations of formulae it has been assumed that $75 \%$ of the $\mathrm{Fe}$ in the micas is $\mathrm{Fe}^{3+}$.

Due to the very fine-grained nature of the samples, the results obtained by AEM were sometimes rejected due to overlap of the beam on material other than the mineral analysed. When mica contamination was slight, the chlorite formula was recalculated after subtracting the proportions of elements determined by normalizing to the $\mathrm{K}$ and $\mathrm{Na}$ contents, resulting in a formula based on 28 negative charges (Nieto, 1997).

\section{Electron microprobe}

The EMPA analyses of detrital micas were carried out using a Cameca SX50 electron microprobe operated at $20 \mathrm{kV}$, with a beam current of $30 \mathrm{nA}$ and a beam diameter of $<5 \mu \mathrm{m}$. The 
standards were: albite, orthoclase, periclase, wollastonite and synthetic oxides $\left(\mathrm{Al}_{2} \mathrm{O}_{3}, \mathrm{Fe}_{2} \mathrm{O}_{3}\right.$, $\mathrm{MnTiO}_{3}$ ). Data were reduced using the procedures of Pouchou \& Pichoir (1985).

\section{RESULTS}

\section{Mineralogy and crystal-chemical parameters}

The XRD patterns of bulk samples show that quartz and white mica, primarily phengite, are the principal phases in all samples; trioctahedral chlorite is very common; smectite, mixed-layered illite-smectite and intermediate $\mathrm{Na}-\mathrm{K}$ mica, paragonite, feldspars, carbonates and hematite are present only in some samples (Table 1). A ditrioctahedral chlorite, sudoite according to Fransolet and Schreyer's (1984) criteria, has been detected in samples from the La Santa and Morrón de Totana units. The XRD patterns of sudoite usually show a distinctly more intense (003) reflection, characteristic of Al-rich chlorites. In general, the mineral assemblages are similar and typical of very lowgrade metamorphism.

The basal spacing of mica is $\sim 9.98 \AA(\sigma=0.01)$, varying with no clear trend throughout the sequence. An overall average value of $9.019 \AA(\sigma$ $=0.010)$, obtained for the $b$ cell parameter (Table 1), is consistent with medium-pressure regional metamorphism according to Guidotti \& Sassi (1986).

Figure 2 shows the IC values for the $<2 \mu \mathrm{m} v s$. $<2 \mu \mathrm{m}$ EG-treated fractions corresponding to all units except for the Los Molinos Unit, for which paragonite is a major phase whose peaks interfere with measurement of IC values. The IC values of the $<2 \mu \mathrm{m}$ fraction for the Morrón de Totana Unit correspond to the zone of diagenesis, with significant variation in values in different samples, as typical of that grade. For the La Santa Unit, the data indicate late diagenetic conditions. The IC values vary the least for samples from the Yéchar Unit, and correspond to the low anchizone (according to the nomenclature of Merriman \& Peacor, 1999). In addition, Fig. 2 shows that, for the Morrón de Totana samples, the IC values of the $<2 \mu \mathrm{m}$ fraction are larger than those of the EG-treated samples, implying the presence of smectite layers interstratified with illite. The IC values for the bulk samples are generally smaller than those of the $<2 \mu \mathrm{m}$ separates, as consistent with a significant contribution of detrital mica in the untreated samples (Table 1).

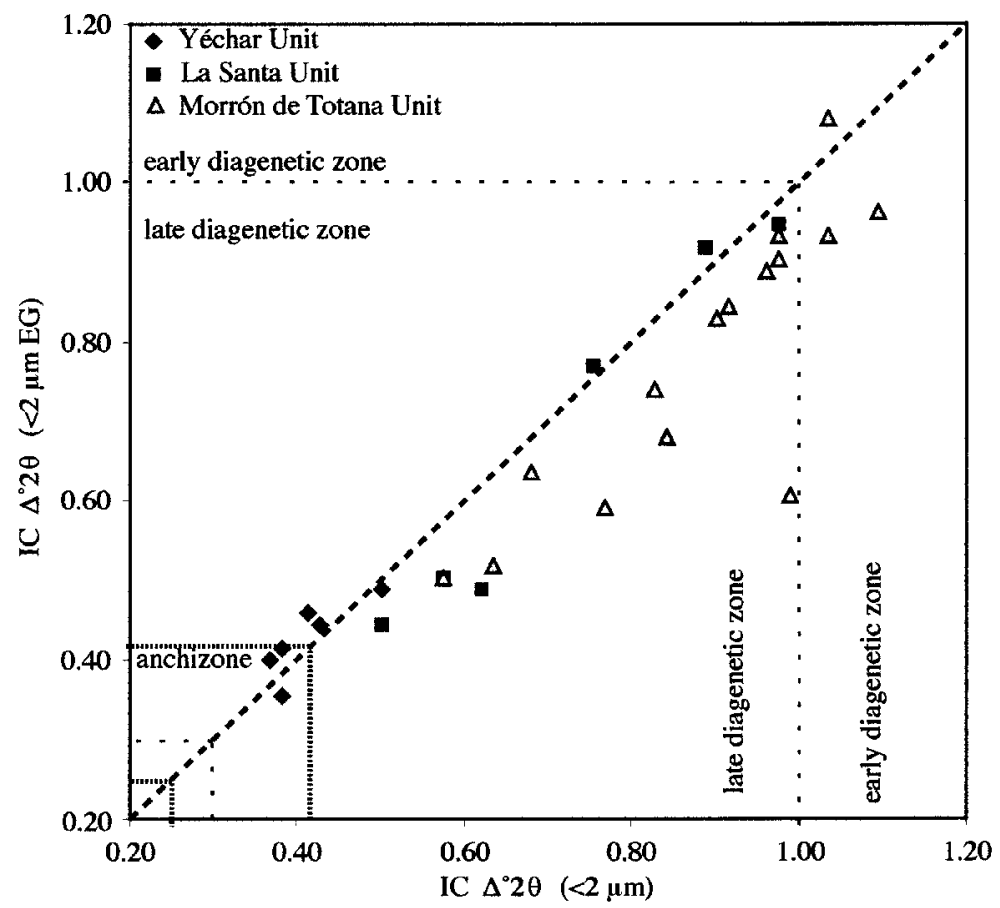

FIG. 2. Plot of IC values for the $<2 \mu \mathrm{m}$ untreated vs. $<2 \mu \mathrm{m}$ EG-treated fractions. 
TABLE 1. Crystal-chemical parameters and bulk mineralogy determined by XRD.

\begin{tabular}{|c|c|c|c|c|c|c|c|c|c|}
\hline \multirow[b]{3}{*}{ Samples } & \multirow{2}{*}{\multicolumn{2}{|c|}{$d_{001}$}} & \multicolumn{3}{|c|}{ White mica } & \multirow[b]{2}{*}{ (CIS) } & \multirow{2}{*}{\multicolumn{2}{|c|}{$\begin{array}{c}\text { Chlorite } \\
d_{001}\end{array}$}} & \multirow{3}{*}{$\begin{array}{l}\text { Mineral composition } \\
\text { Qtz, K-white mica } \\
\text { (all the samples) }\end{array}$} \\
\hline & & & & Illite & crystallinity & & & & \\
\hline & $<2 \mu \mathrm{m}$ & bulk & $b$ & $<2 \mu \mathrm{m}$ & $<2 \mu \mathrm{m} \mathrm{EG}$ & bulk & $<2 \mu \mathrm{m}$ & bulk & \\
\hline \multicolumn{10}{|c|}{ Los Molinos Unit } \\
\hline Es-101 & 9.972 & 9.966 & 9.012 & - & - & - & 14.2 & 14.2 & Chl, Hem, Pg, Cc, Dol, Sm \\
\hline Es-102 & 9.978 & 9.980 & 9.002 & - & - & - & 14.2 & 14.2 & $\mathrm{Chl}, \mathrm{Hem}, \mathrm{Pg}, \mathrm{Cc}, \mathrm{Sm}$ \\
\hline Es- 103 & 9.970 & 9.975 & - & - & - & - & 14.2 & 14.2 & Chl, Hem, Kfs, Pg, Cc, Sm \\
\hline Es- 104 & 9.969 & - & - & - & - & - & 14.2 & - & Chl, Hem, Pg, Cc, Sm \\
\hline \multicolumn{10}{|c|}{ Yéchar Unit } \\
\hline Es-51 & 9.977 & 9.972 & 9.019 & 0.38 & 0.35 & 0.20 & 14.17 & 14.17 & Chl, Hem, Dol, Sm \\
\hline Es-52 & 9.974 & 9.970 & 9.016 & 0.41 & 0.46 & 0.22 & 14.17 & 14.16 & Chl, Kfs, Sm \\
\hline Es-53 & 9.978 & 9.971 & 9.016 & 0.37 & 0.40 & 0.22 & 14.17 & 14.17 & Chl, Hem, Kfs, Sm \\
\hline Es-54 & 9.979 & 9.978 & 9.019 & 0.41 & - & 0.25 & 14.16 & 14.16 & Chl, Hem, Sm \\
\hline Es-55 & 9.975 & 9.987 & - & 0.38 & 0.41 & 0.20 & 14.16 & 14.18 & $\mathrm{Chl}, \mathrm{Hem}, \mathrm{Cc}, \mathrm{Sm}$ \\
\hline Es-56 & 9.957 & 9.967 & 9.010 & 0.43 & 0.44 & 0.22 & - & - & Hem, Cc, Dol \\
\hline Es-57 & 9.958 & - & 9.019 & 0.50 & 0.49 & - & 14.18 & - & Chl, Cc, Dol \\
\hline \multicolumn{10}{|c|}{ La Santa Unit } \\
\hline Es-1 & 9.976 & - & 9.019 & 0.50 & 0.44 & 0.71 & 14.17 & - & Chl, Hem, Kfs, Sm \\
\hline Es-2 & 9.974 & 9.977 & 9.003 & 0.62 & 0.49 & 0.29 & 14.17 & 14.17 & Chl, Kfs, Sm \\
\hline Es-3 & 9.963 & - & 9.018 & 0.58 & 0.50 & 0.31 & 14.20 & - & $\mathrm{Chl}, \mathrm{Hem}, \mathrm{Cc}, \mathrm{Sm}$ \\
\hline Es-4 & 9.987 & 9.987 & 9.007 & 0.75 & 0.77 & 0.49 & 14.16 & 14.17 & Chl, Hem, Dol \\
\hline Es-5 & 9.993 & 9.983 & - & 0.93 & - & 0.84 & 14.17 & 14.17 & Su, Chl, Hem, Ill-Pg, Pg \\
\hline Es-6 & 9.988 & 9.982 & - & 0.89 & 0.92 & 0.78 & 14.17 & 14.16 & Chl, Hem, Cc, Dol, Ill-Pg \\
\hline Es-7 & 9.990 & 9.981 & - & 0.98 & 0.95 & 0.69 & 14.18 & 14.19 & Chl, Hem, Cc, Dol \\
\hline Es-8 & 9.985 & 9.975 & 9.007 & 0.66 & - & 0.46 & 14.17 & 14.16 & Chl, Hem, Cc, Dol, Ill-Pg \\
\hline \multicolumn{10}{|c|}{ Morrón de Totana Unit } \\
\hline Es-71 & 9.977 & - & 8.994 & - & - & - & - & - & Chl, Kfs, Hem \\
\hline Es-72 & - & - & - & - & - & - & - & - & Chl, Hem, Gt \\
\hline Es-73 & 9.970 & - & - & - & - & - & - & - & Kfs, Cc, Dol \\
\hline Es-74 & 9.991 & - & - & 0.69 & 0.71 & - & - & - & Kfs, Hem, Gt \\
\hline Es-75 & 9.972 & 9.991 & 8.989 & 0.68 & 0.64 & - & - & - & Chl, Kfs, Hem, Dol \\
\hline Es-76 & 10.005 & - & 0.64 & 0.52 & - & - & - & - & Chl, Hem, Gt, Dol \\
\hline Es-77 & 9.979 & - & 9.011 & 0.77 & 0.59 & 0.83 & - & - & Chl, Hem, Dol, I-S \\
\hline Es-78 & 9.972 & - & 0.84 & 0.68 & 0.71 & - & - & - & $\mathrm{Chl}, \mathrm{Cc}, \mathrm{Sm}, \mathrm{Gt}$ \\
\hline Es-79 & 9.984 & - & 9.028 & 0.98 & 0.90 & 0.61 & - & - & Chl, Kfs, Hem, Dol \\
\hline Es-70 & 9.984 & - & 0.96 & 0.89 & 0.35 & 14.16 & 14.18 & - & Dol, Chl, Sm \\
\hline Es-81 & 9.980 & - & - & 0.99 & 0.61 & - & 14.2 & - & Chl, Hm, Cc, Dol \\
\hline Es-82 & 9.972 & - & - & 0.90 & 0.83 & - & - & - & Chl, Hm, Cc, Dol, Sm \\
\hline Es-85 & 9.972 & - & 9.008 & 0.58 & 0.50 & 0.50 & 14.2 & - & $\mathrm{Chl}, \mathrm{Su}, \mathrm{Hem}, \mathrm{Sm}, \mathrm{Kfs}$ \\
\hline Es-86 & 9.951 & 9.977 & 9.013 & 0.92 & 0.84 & 0.47 & 14.2 & - & $\mathrm{Chl}, \mathrm{Su}, \mathrm{Hem}, \mathrm{Sm}, \mathrm{Kfs}$ \\
\hline Es-87 & 9.974 & 9.008 & 0.83 & - & 0.50 & 14.2 & - & - & $\mathrm{Chl}, \mathrm{Su}, \mathrm{Hem}, \mathrm{Sm}, \mathrm{Kfs}$ \\
\hline Es-91 & 9.974 & - & - & 1.04 & 1.08 & 0.93 & - & - & Chl, Hem, Kfs \\
\hline Es-92 & 9.972 & - & 9.028 & 0.83 & 0.74 & 0.86 & - & - & Chl, Dol, Kfs \\
\hline Es-93 & 9.980 & 9.983 & - & 1.09 & 0.96 & 0.61 & - & - & Chl, Hem, Dol \\
\hline Es-94 & 9.964 & 9.985 & 9.024 & 0.98 & 0.93 & 0.80 & - & - & Chl, Hem, Dol, Kfs \\
\hline Es-95 & 9.978 & - & 9.027 & 1.04 & 0.93 & - & - & - & Dol \\
\hline
\end{tabular}

Mineral abbreviations according to Kretz (1983), Ill-Pg: Intermediate Na-K mica, I-S: Illite-smectite interstratified layers, Su: Sudoite. In bold, samples studied by TEM.

\section{Whole-rock analyses}

Chemical analyses of the major elements of selected samples were carried out using X-ray fluorescence (XRF) in a Philips PW 1040/10 spectrometer at the C.I.C. The data (Table 2) were compared with the average of Post-Archaean 
TABLE 2. Whole-rock analyses of major elements (wt.\% oxide).

\begin{tabular}{lcccccccccccc}
\hline Samples & $\mathrm{SiO}_{2}$ & $\mathrm{TiO}_{2}$ & $\mathrm{Al}_{2} \mathrm{O}_{3}$ & $\mathrm{Fe}_{2} \mathrm{O}_{3}$ & $\mathrm{FeO}$ & $\mathrm{MnO}$ & $\mathrm{MgO}$ & $\mathrm{CaO}$ & $\mathrm{Na}_{2} \mathrm{O}$ & $\mathrm{K}_{2} \mathrm{O}$ & $\mathrm{P}_{2} \mathrm{O}_{5}$ & L.O.I. \\
\hline Es-102 & 53.40 & 0.77 & 17.90 & 5.57 & 1.00 & 0.13 & 1.58 & 7.22 & 1.52 & 2.54 & 0.13 & 8.47 \\
Es-51 & 52.70 & 0.83 & 17.52 & 4.41 & 1.90 & 0.14 & 5.14 & 3.59 & 0.28 & 5.03 & 0.16 & 8.45 \\
Es-52 & 76.20 & 0.93 & 12.10 & 0.70 & 1.20 & - & 1.85 & 0.37 & 1.43 & 2.51 & 0.17 & 2.39 \\
Es-53 & 59.90 & 0.89 & 18.90 & 5.83 & 1.40 & - & 2.92 & 0.21 & 0.43 & 4.89 & 0.14 & 4.08 \\
Es-56 & 66.40 & 0.61 & 12.00 & 3.50 & 0.20 & - & 1.90 & 3.84 & 0.11 & 4.27 & 0.12 & 6.16 \\
Es-57 & 61.47 & 0.65 & 11.54 & 3.69 & 0.86 & 0.05 & 3.54 & 5.22 & - & 4.03 & 0.12 & 9.09 \\
Es-1 & 60.08 & 0.86 & 18.20 & 5.24 & 1.70 & - & 2.99 & 0.29 & 0.31 & 4.84 & 0.14 & 4.16 \\
Es-2 & 65.10 & 0.91 & 17.70 & 1.39 & 1.90 & - & 3.22 & 0.33 & 0.38 & 4.27 & 0.16 & 4.70 \\
Es-3 & 51.52 & 0.89 & 20.30 & 5.90 & 1.85 & 0.06 & 4.29 & 2.41 & - & 6.19 & 0.18 & 6.42 \\
Es-5 & 62.60 & 0.90 & 17.50 & 6.88 & 0.20 & - & 2.63 & 0.30 & 0.65 & 2.37 & 0.12 & 4.93 \\
Es-6 & 68.91 & 0.80 & 13.21 & 4.34 & 0.86 & 0.09 & 1.69 & 2.93 & 0.50 & 2.34 & 0.10 & 5.36 \\
Es-7 & 51.58 & 0.87 & 21.09 & 6.71 & 1.42 & 0.06 & 2.75 & 3.79 & 0.86 & 3.47 & 0.18 & 7.66 \\
Es-75 & 72.38 & 0.71 & 12.51 & 2.38 & 1.18 & 0.03 & 1.54 & 1.43 & - & 3.37 & 0.09 & 4.38 \\
Es-77 & 34.42 & 0.55 & 12.52 & 5.16 & 0.87 & 0.05 & 9.56 & 13.37 & - & 3.61 & 0.09 & 21.60 \\
Es-79 & 49.96 & 0.64 & 10.62 & 3.35 & 1.29 & 0.24 & 6.76 & 9.35 & - & 3.01 & 0.08 & 15.90 \\
Es-86 & 76.00 & 0.83 & 12.08 & 1.22 & 1.44 & 0.02 & 2.05 & 0.48 & 0.61 & 3.24 & 0.14 & 2.82 \\
Es-87 & 62.85 & 1.06 & 17.05 & 5.16 & 1.75 & 0.04 & 2.99 & 0.34 & 0.33 & 4.93 & 0.18 & 3.96 \\
Es-91 & 58.81 & 0.83 & 17.07 & 4.09 & 1.51 & 0.03 & 3.38 & 2.17 & - & 5.69 & 0.17 & 6.45 \\
Es-95 & 59.13 & 0.75 & 18.02 & 3.68 & 1.04 & 0.02 & 4.10 & 0.95 & 0.09 & 7.17 & 0.16 & 5.20 \\
& & & & & & & & & & & & \\
\hline
\end{tabular}

Australian Shales (PAAS) (Taylor \& McLennan, 1985). The values for samples of this study are similar to them. The loss on ignition (L.O.I.) is very large in some samples because of the presence of carbonates.

\section{Electron microscopy observations (SEM and TEM)}

Textural aspects. Due to the fine-grained character of these rocks, characterization of textures is possible only by TEM, except for the highest metamorphic-grade samples (Es-102 and Es-53), for which grain sizes are large enough to be resolved by BSE imaging. The HRTEM characterization confirms the general mineralogical data determined by XRD for the different units of the studied area and have allowed us to clarify some specific relations, e.g. the mixed-layered illite-smectite in the Morrón de Totana Unit.

Los Molinos Unit samples are phyllosilicate-rich phyllites with well-developed slaty cleavage (Fig. 3a), composed of preferentially oriented mica and chlorite alternating with deformed, elongated quartz grains, carbonate aggregates and hematite grains. Paragonite and muscovite coexist as separate crystals. Lattice-fringe images show that both micas and chlorite occur as large, defect-free crystals, more than several thousand angstroms thick
(Fig. 4). Lattice-fringe images (not shown) with both $00 l$ and $h k l$ fringes show that crystals are composed virtually entirely of coherently related layers, but with some stacking disorder in chlorite. These features are in accord with the typical greenschist facies of the Alpujarride Complex (Azañón \& Crespo-Blanc, 2000). On the other hand, dioctahedral smectite commonly occurs, replacing layers of trioctahedral chlorite, described by Nieto et al. (1994) as the result of retrograde alteration by hydrothermal fluids.

The sample studied from the basal portion of the Yéchar Unit (Es-53) is a quartz-rich slate with welldeveloped cleavage (Fig. 3b). High-resolution images show that the main phyllosilicate is K-rich dioctahedral mica, with lesser amounts of chlorite and dioctahedral smectite, the smectite occurring as altered layers of primary, metamorphic chlorite. Although phyllosilicates generally form parallel or low-angle intergrowths preferentially oriented parallel to cleavage, Fig. 5 shows a low-magnification image with well-defined high-angle grain boundaries of interlocking grains. Such textures are typical of a metamorphic origin. The packets are $500 \AA$ thick (Fig. 6), much smaller than typical detrital grains (>5000 ̊). They also have compositions which differentiate them from detrital micas, as described below (see chemical characterization of phyllosilicates). In general, the phyllosilicate 


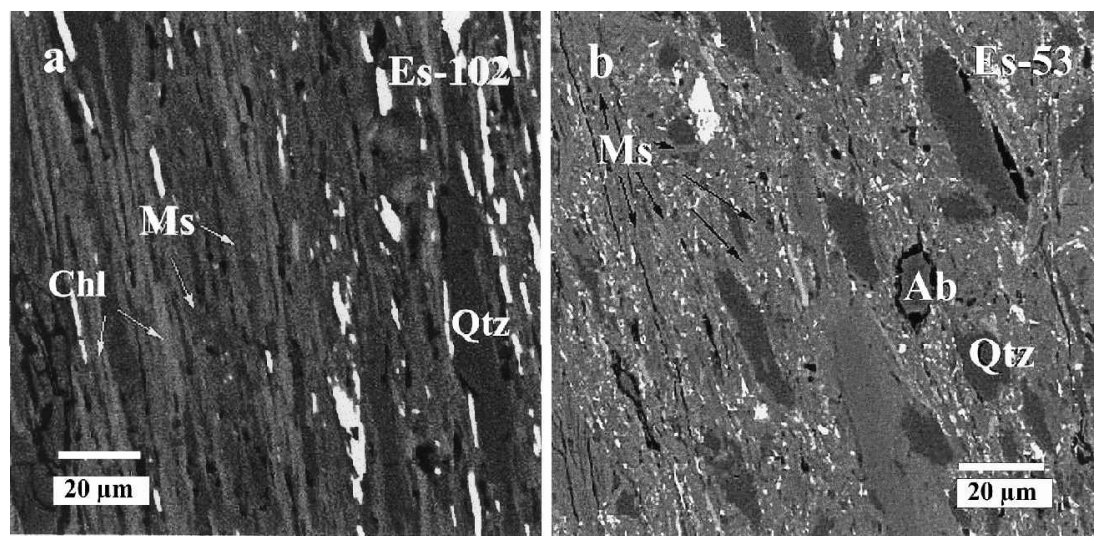

FIG. 3. BSE images showing the well-developed slaty cleavage of two samples: (a) Es-102 (Los Molinos Unit), a phyllite in which the grains with the brightest contrast are hematite and the darkest ones, quartz. Chlorite and muscovite grains are characterized by their elongated habit and intermediate brightness (stronger in chlorite than in muscovite) (b) Es-53 (Yéchar Unit), in which stretched quartz grains are more abundant and responsible for its semipelitic character; grains with high contrast are hematite or $\mathrm{TiO}_{2}$. Muscovite crystals are indicated by arrows.

packets are almost defect-free with only rare layer terminations (Fig. 6). The polytypes are $2 M$ for micas and semi-random for chlorites.

Two samples have been studied from the La Santa Unit. Sample Es-2, a chlorite-rich shale, is from the basal part of the unit, and sample Es-5, a quartz-rich shale, is from the upper part. In Es-2, elongated quartz-rich and phyllosilicate-rich domains alternate at the scale of millimetres parallel to slaty cleavage. The principal phyllosilicate is muscovite with well-defined $2 M$ polytypism. The $(h k 0)$ reflections tend to be spread normal to $c^{*}$ much more than in sample Es-53 due to the presence of thinner packets in subparallel orientations. The trioctahedral chlorite (clinochlore) is often altered to dioctahedral smectite, as determined in part by AEM data, as a result of retrograde alteration processes (e.g. Fig. 7 in Nieto et al., 1994). The most common defects are layer terminations, voids, low-angle grain boundaries, and dislocations.

Sample Es-5 shows incipient slaty cleavage, defined by subparallel, preferentially oriented packets of illite, sudoite, trioctahedral chlorite, paragonite and intermediate $\mathrm{Na}-\mathrm{K}$ mica, as illustrated in Fig. 7. Hematite is commonly included

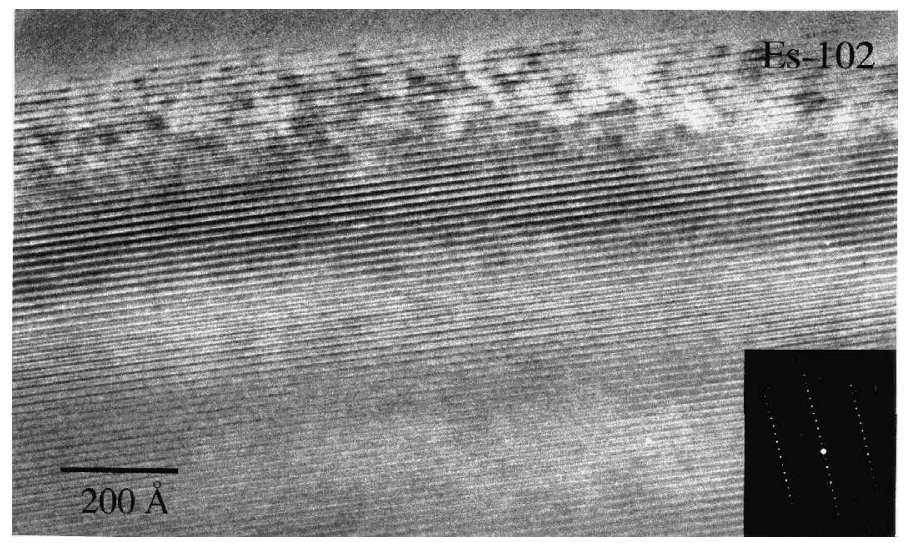

FIG. 4. Lattice-fringe image, showing a portion of a defect-free, well-crystallized chlorite packet of metamorphic origin in phyllite Es-102 (Los Molinos Unit). 


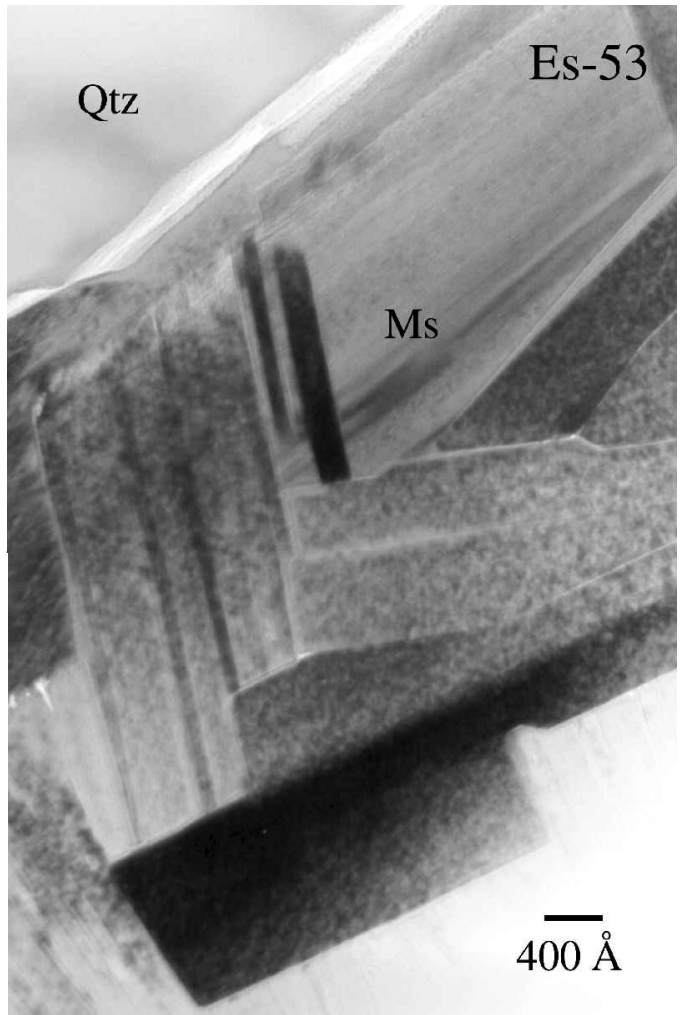

FIG. 5. Low-magnification image with well-defined high-angle grain boundaries and interlocking relations among muscovite crystals (Yéchar Unit). within illite packets as elongated individual grains up to $\sim 300 \times 500 \AA$ in size or as aggregates (Fig. 7); they show up clearly due to their dark contrast. Sudoite and chlorite were identified on the basis of SAED and AEM data. Separate grains of each were observed to be intergrown, with textures typical of metamorphic origins for both. Grain sizes of sudoite $(>500 \AA)$ and clinochlore are approximately equal, implying formation of both at grades which were not substantially different. However, where grains of each intersect at high angles, the sudoite ubiquitously transects clinochlore packets. As shown in Fig. 8, clinochlore, but not sudoite, may exhibit strain contrast. These relations imply, but do not prove, that sudoite post-dated clinochlore. Obvious alteration of clinochlore to dioctahedral smectite was ubiquitous, but possible alteration effects were rare in sudoite, occurring as defects such as voids and wavy layers. Because the composition of sudoite is similar to that of dioctahedral smectite, it was not possible to verify the presence of small numbers of smectite layers with AEM data. Nevertheless, the observations clearly show that alteration of chlorite to smectite was relegated entirely or almost entirely to clinochlore.

Muscovite occurs in crystals which average $\sim 500 \AA$ in thickness and are characterized by $2 M$ polytypism, features which are typical of metamorphic mica of anchizonal grade. The Na-K mica occurs in packets of similar thickness. The

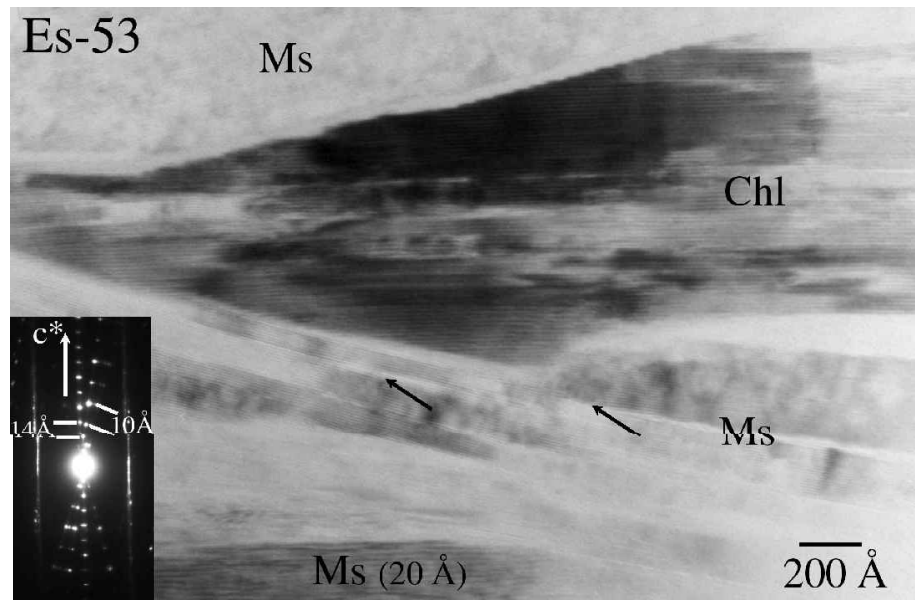

FIG. 6. Lattice-fringe image showing the relation between mica and chlorite packets. The arrows indicate the position of layer terminations. The inset SAED pattern illustrates the low-angle relation between the two phases (Yéchar Unit). 


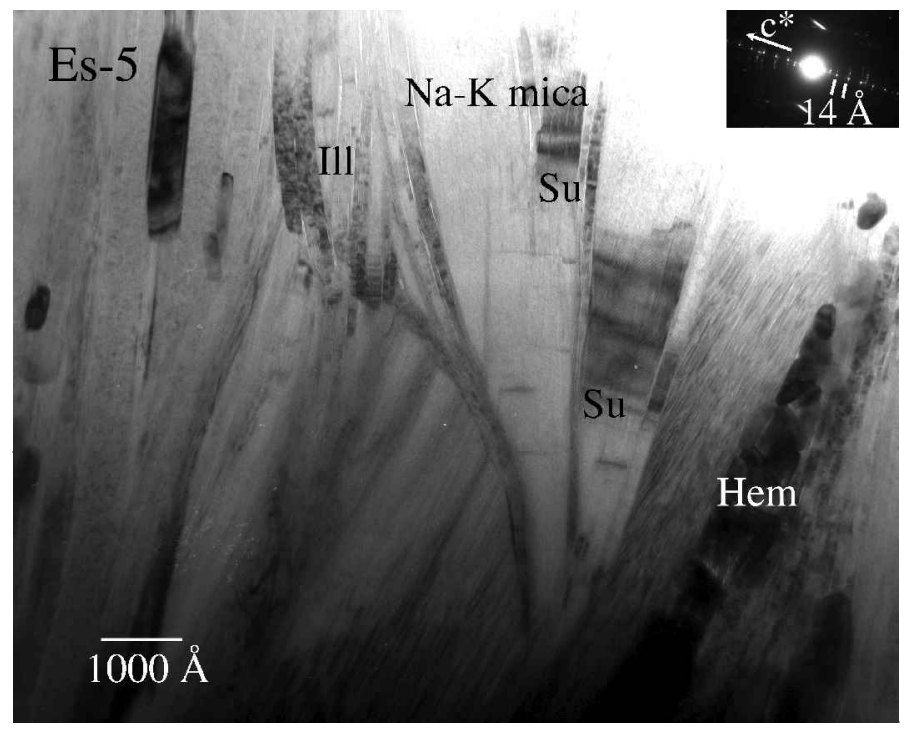

FIG. 7. Textural relations between phyllosilicates (sudoite, illite, Na-K mica) and hematite (dark contrast) (La Santa Unit).

composition (see below) is quite variable, corresponding to Na-rich muscovite commonly, but some grains have compositions within the limits of the solvus between muscovite and paragonite, and thus are metastable. Na-K micas give SAED patterns which have relatively sharp reflections over a large range, as consistent with large, defect-free crystals.

Sudoite crystals comprise units with $14 \AA$ periodicities which in some areas are $28 \AA$. Lattice-fringe images show the presence of inter- stratified individual $7 \AA$ layers, which in some areas form small packets containing no more than eight $7 \AA$ layers. The AEM analyses (see below) of such areas are typical of those of homogeneous sudoite containing only $14 \AA$ layers, implying a composition of the $7 \AA$ layers similar to that of sudoite, and not to an exotic septechlorite such as kaolinite or berthierine. The contrast of both $14 \AA$ and $7 \AA$ fringes appear to be identical, further consistent with a close chemical relation.

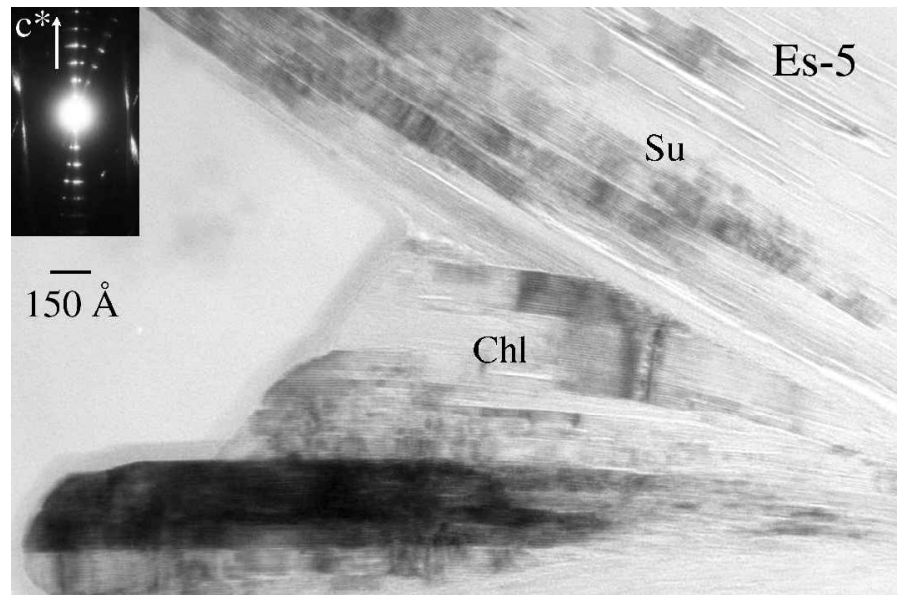

FIG. 8. Lattice-fringe image showing the coexistence of two types of chlorite: trioctahedral chlorite (chl) and sudoite (su). Sudoite transects chlorite which shows strain contrast associated with curved and kinked layers. Identifications were based in part on AEM analyses (see Table 6, Es-5/11 and /12 analyses) (La Santa Unit). 


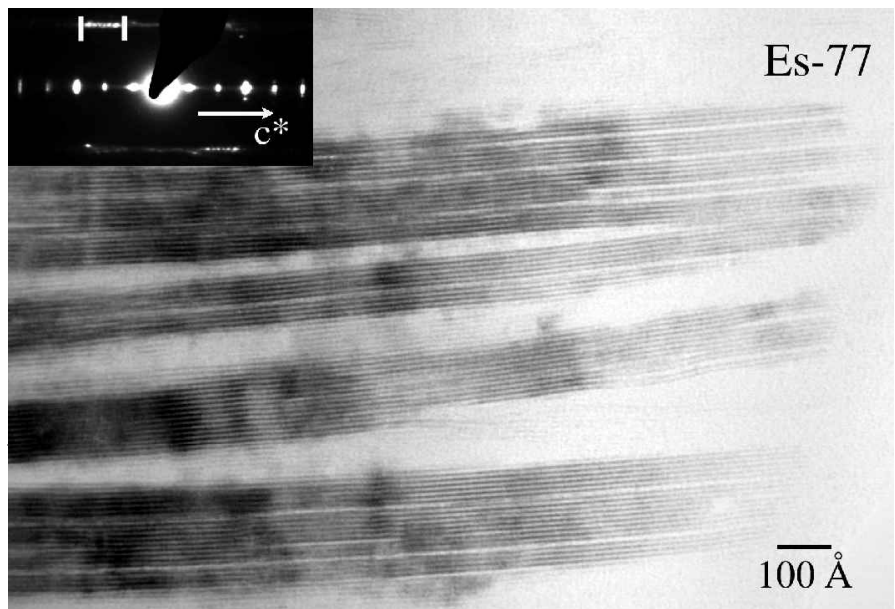

FIG. 9. TEM image showing $10 \AA$ periodicity in R4, illite-rich I-S. Contrast differences imply the presence of illite-like (the dark fringes) and smectite-like (the light fringes) layers. Packets usually have four or more illite layers and the SAED pattern shows predominantly $50 \AA$ periodicity (Morrón de Totana Unit).

Three samples corresponding to different but equivalent levels were selected from the Morrón de Totana Unit for TEM study (see Fig. 1, pelitic rocks intercalated with carbonate rocks): Es-77, at the bottom of the unit, Es-86, which is located in an intermediate position and Es-95, from the top of the cross-section. There is no incipient slaty cleavage in these samples. Sample Es-77 is a very fine-grained rock consisting of quartz, white mica, chlorite and aggregates of carbonate grains. Minor hematite produces a deep red colour. Lattice-fringe images show that dioctahedral clay minerals have 10 and $20 \AA$ periodicities, occur as packets $100-200 \AA$ thick and have subparallel orientations. According to Guthrie \& Veblen (1989), smectite and illite interlayers can produce different contrast and can only be differentiated in lattice fringe-images obtained with well-defined electron beam (001) orientations and defocus conditions. Such contrast differences were observed in several lattice-fringe images. The light contrast for fringes in Fig. 9 represents the smectite interlayer, as shown in part

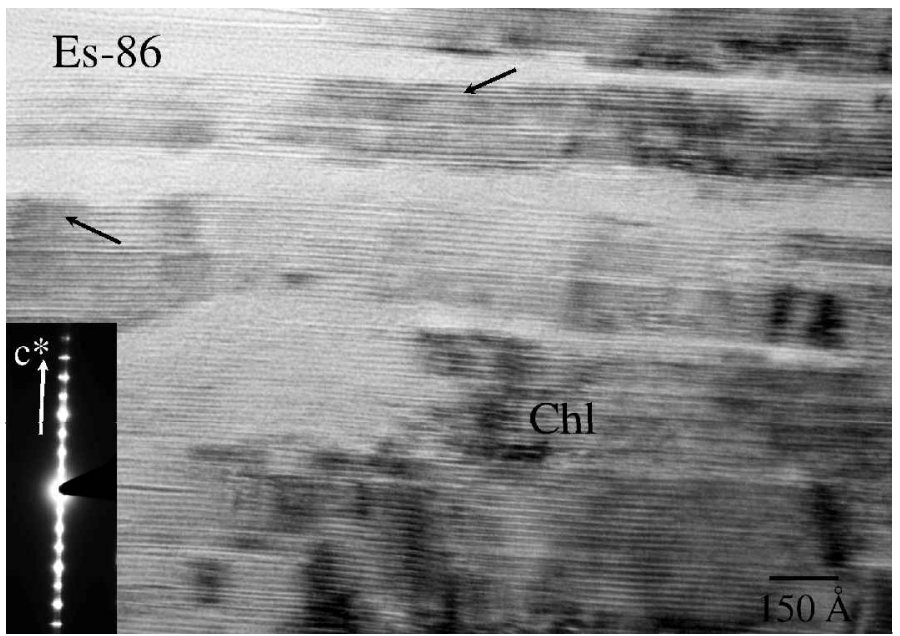

FIG. 10. Trioctahedral chlorite with intercalations of $10 \AA$ layers (upper arrow) which damage quickly under the electron beam. The chlorite packets show strain contrast, microfolds and $7 \AA$ periodicities corresponding to berthierine (left arrow) or greater values, e.g. $28 \AA$ (see analysis in Table 6, Es-86/7) (Morrón de Totana Unit). 


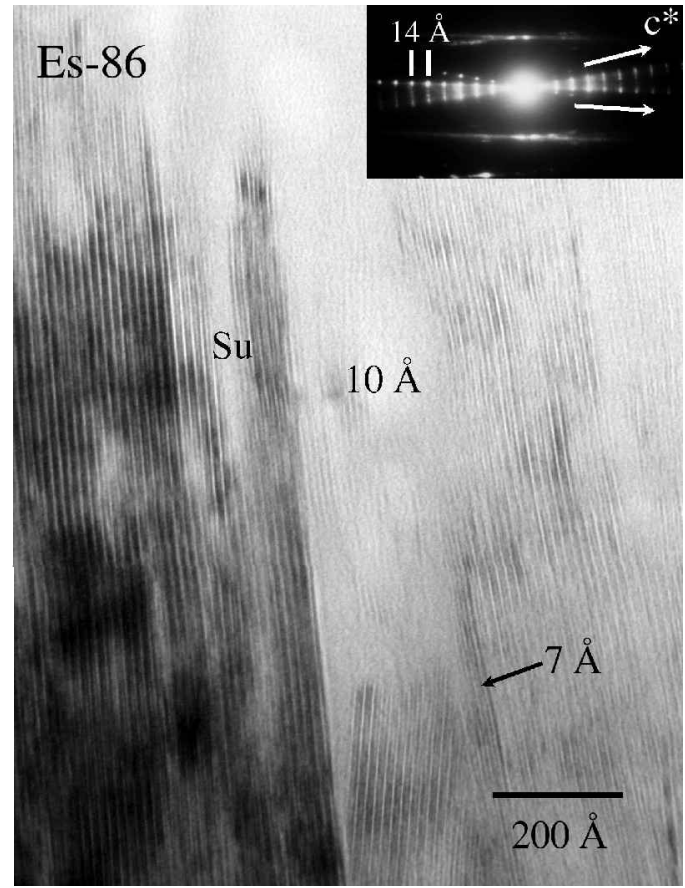

FIG. 11. Di-trioctahedral chlorite (sudoite), very similar in appearance to the trioctahedral chlorite shown in Fig. 10. $7 \AA$ layers are marked by an arrow and $10 \AA$ layers are present in the poorly resolved area in the centre of the image (see analysis in Table 6, Es-86/2)

(Morrón de Totana Unit).

by the continuity of such fringes with open interlayer spaces produced by contraction due to dehydration. The sequence, on average, is that of R4 mixed-layering, i.e. a single smectite-like interlayer between four or more illite-like interlayers. Although some packets with more than four layers of illite are present, repeats of four illite-like layers predominate, as shown by the $50 \AA$ periodicity of SAED patterns (Fig. 9, inset). The illite-smectite (I-S) has typical $1 M_{d}$ polytypism. The observation of smectite interstratified with illite is in accord with the changes observed in XRD diagrams after EG treatment (Fig. 2). In addition, AEM analyses of areas similar to that of Fig. 9 have relatively high $\mathrm{Si}$ and minor $\mathrm{Ca}$ contents, further confirming the mixed layering.

Some packets which give rise to fringes with $10 \AA$ spacing produce SAED patterns typical of two-layer polytypism. The contrast of all fringes is relatively constant. Such packets have thicknesses typical of diagenetic clays and two orders of magnitude smaller than typical detrital grains. The compositions of such grains (see below) have interlayer-cation contents typical of illite. They are therefore inferred to be illite which formed during late diagenesis and coexisting with the R4 I-S.

Sample Es-86 is composed mainly of detrital grains of quartz, randomly-oriented, grains of chlorite, and white mica, all immersed in a phyllosilicate-rich, fine-grained matrix. At the TEM scale, chlorite is the most common phyllosilicate in the matrix. As in sample Es-5, trioctahedral chlorite and sudoite coexist. There are interstratified packets of $10 \AA$ layers only a few layers thick $(<150 \AA)$ which are quickly damaged

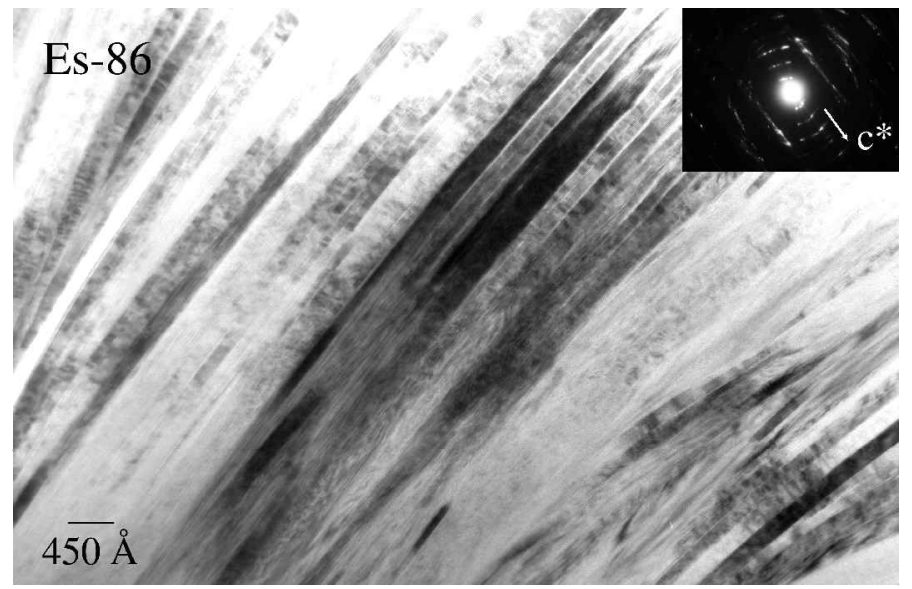

FIG. 12. Low-magnification image illustrating illite-like packets. The inset SAED pattern shows only a small number of diffuse, poorly defined reflections. The packets are 100-200 ̊ thick (Morrón de Totana Unit). 
under the electron beam (Figs 10 and 11). The AEM analyses of such material show an enhanced Si content and the presence of small concentrations of alkali cations. These data are consistent with retrograde alteration of chlorite as observed by Nieto et al. (1994). They differ, however, from the results of Nieto et al. (1994) and those described above for sample Es-5, in that both tri-trioctahedral and di-trioctahedral chlorite are affected. In TEM images, strain features in chlorites, such as contrast normal to the layers, or microfolds, were observed (Fig. 10). Mica is less abundant than sudoite, occurring in packets $100-400 \AA$ thick. The SAED patterns exhibit $2 M$ polytypism, but with diffuseness parallel to $c^{*}$ in $0 k l$ rows. At low magnification, subparallel and slightly curved illite- or illitesmectite-like packets are present; they coalesce, have abundant layer terminations and show intense contrasts (Fig. 12).

Sample Es-95 is a very fine-grained rock made up of large, detrital grains of quartz in a finegrained matrix of phyllosilicates, mainly white micas, and opaque minerals. Some biotite grains were observed, as verified by AEM data. Biotite was observed only in separated grains on holey
C-coated $\mathrm{Cu}$ grids, so it is not possible to describe the textural relations for it. Authigenic biotite is inconsistent with the low grade of this sample, however, and it is therefore inferred to be of detrital origin. The AEM analyses show deviations from pure biotite, however, as consistent with alteration to chlorite, the usual process in detrital biotite in rocks undergoing diagenesis. Lattice-fringe images of ion-milled samples show that individual mica packets are very thin, with no more than 10 layers, isolated and dispersed in a matrix consisting of material which gives no SAED pattern. These packets are wavy, discontinuous and with anastomosing layers (Fig. 13). Despite these textural features, SAED data indicate that there are $2 M$ and $1 M_{d}$ polytypes.

For all samples, prismatic crystals of Ti-oxide, dispersed $\mathrm{Fe}$-oxyhydroxides, zircon and tourmaline are common accessory minerals.

\section{Chemical characterization of phyllosilicates}

Dioctahedral mica. Table 3 shows the composition of K-rich dioctahedral micas of authigenic or metamorphic origin, corresponding to the samples

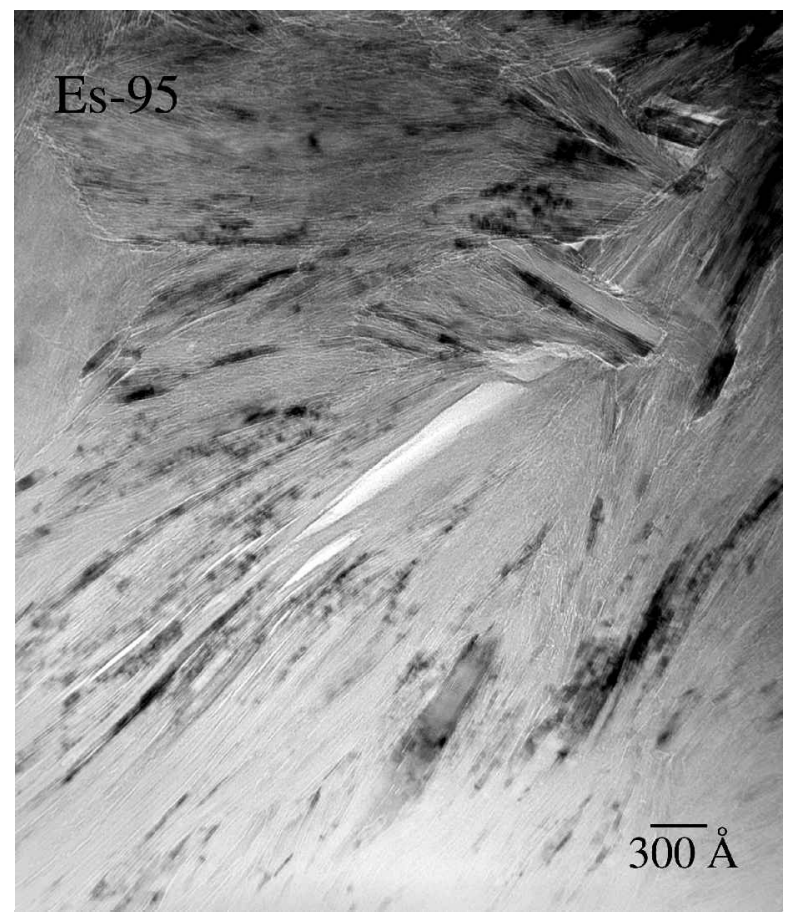

FIG. 13. General aspect of sample Es-95. The image shows arrays of wavy, discontinuous and anastomosing packets of illite and smectite (Morrón de Totana Unit). 
TABLE 3. Representative chemical compositions for K-rich dioctahedral micas normalized to $\mathrm{O}_{10}(\mathrm{OH})_{2}$.

\begin{tabular}{|c|c|c|c|c|c|c|c|c|c|c|}
\hline & $\mathrm{Si}$ & ${ }^{\mathrm{IV}} \mathrm{Al}$ & ${ }^{\mathrm{VI}} \mathrm{Al}$ & $\mathrm{Fe}$ & $\mathrm{Mg}$ & $\mathrm{Ti}$ & ${ }^{\mathrm{VI}_{\Sigma}}$ & $\mathrm{K}$ & $\mathrm{Na}$ & $\Sigma$ inter. \\
\hline \multicolumn{11}{|c|}{ Los Molinos Unit (1) } \\
\hline Es-102/1/3 & 3.37 & 0.63 & 1.78 & 0.10 & 0.08 & 0.02 & 1.98 & 0.75 & 0.08 & 0.85 \\
\hline Es-102/2/1 & 3.08 & 0.92 & 1.95 & 0.05 & 0.01 & 0.01 & 2.02 & 0.82 & 0.09 & 0.91 \\
\hline Es-102/3/1 & 3.19 & 0.81 & 1.91 & 0.05 & 0.03 & 0.01 & 2.00 & 0.77 & 0.12 & 0.90 \\
\hline Es-102/3/2 & 3.14 & 0.86 & 1.88 & 0.06 & 0.07 & 0.01 & 2.02 & 0.72 & 0.21 & 0.93 \\
\hline \multicolumn{11}{|c|}{ Yéchar Unit (1) } \\
\hline Es-53/1/1 & 3.32 & 0.68 & 1.63 & 0.15 & 0.22 & 0.02 & 2.04 & 0.90 & 0.04 & 0.93 \\
\hline Es-53/1/2 & 3.10 & 0.90 & 1.80 & 0.03 & 0.13 & 0.04 & 2.01 & 0.89 & 0.10 & 0.99 \\
\hline Es-53/2/2 & 3.38 & 0.62 & 1.70 & 0.12 & 0.15 & 0.03 & 2.00 & 0.86 & 0.01 & 0.86 \\
\hline Es- $53 / 2 / 3$ & 3.19 & 0.81 & 1.76 & 0.16 & 0.12 & 0.03 & 2.06 & 0.87 & 0.02 & 0.89 \\
\hline \multicolumn{11}{|c|}{ Yéchar Unit (2) } \\
\hline Es-53 1 & 3.17 & 0.83 & 1.63 & 0.21 & 0.26 & 0.00 & 2.10 & 0.84 & 0.00 & 0.84 \\
\hline Es-53 2 & 3.20 & 0.80 & 1.65 & 0.11 & 0.27 & 0.03 & 2.07 & 0.87 & 0.00 & 0.87 \\
\hline Es-53 3 & 3.17 & 0.83 & 1.55 & 0.25 & 0.24 & 0.02 & 2.06 & 0.93 & 0.00 & 0.93 \\
\hline Es-53 4 & 3.28 & 0.72 & 1.60 & 0.20 & 0.24 & 0.00 & 2.03 & 0.92 & 0.00 & 0.92 \\
\hline Es-53 5 & 3.26 & 0.74 & 1.64 & 0.19 & 0.16 & 0.00 & 1.99 & 0.96 & 0.00 & 0.96 \\
\hline Es-53 6 & 3.26 & 0.74 & 1.58 & 0.20 & 0.28 & 0.00 & 2.06 & 0.89 & 0.00 & 0.89 \\
\hline Es-53 7 & 3.19 & 0.81 & 1.54 & 0.25 & 0.26 & 0.00 & 2.05 & 0.97 & 0.00 & 0.97 \\
\hline Es-53 8 & 3.25 & 0.75 & 1.66 & 0.16 & 0.25 & 0.00 & 2.06 & 0.85 & 0.00 & 0.85 \\
\hline Es-53 9 & 3.24 & 0.76 & 1.67 & 0.19 & 0.19 & 0.00 & 2.05 & 0.85 & 0.00 & 0.85 \\
\hline \multicolumn{11}{|c|}{ La Santa Unit (2) } \\
\hline Es-2 1 & 3.11 & 0.89 & 1.57 & 0.19 & 0.32 & 0.02 & 2.10 & 0.88 & 0.05 & 0.94 \\
\hline Es-2 3 & 3.36 & 0.64 & 1.48 & 0.20 & 0.43 & 0.01 & 2.12 & 0.72 & 0.03 & 0.75 \\
\hline Es-2 6 & 3.13 & 0.87 & 1.56 & 0.24 & 0.29 & 0.01 & 2.10 & 0.75 & 0.17 & 0.92 \\
\hline Es-2 7 & 3.13 & 0.87 & 1.55 & 0.24 & 0.29 & 0.01 & 2.09 & 0.84 & 0.11 & 0.95 \\
\hline Es-2 8 & 3.31 & 0.69 & 1.57 & 0.15 & 0.32 & 0.00 & 2.05 & 0.87 & 0.04 & 0.92 \\
\hline Es-2 10 & 3.28 & 0.72 & 1.60 & 0.18 & 0.27 & 0.03 & 2.08 & 0.68 & 0.08 & 0.75 \\
\hline Es-5 4 & 3.03 & 0.97 & 1.74 & 0.15 & 0.23 & 0.01 & 2.13 & 0.73 & 0.09 & 0.82 \\
\hline Es-5 10 & 3.01 & 0.99 & 1.89 & 0.06 & 0.15 & 0.00 & 2.10 & 0.65 & 0.21 & 0.86 \\
\hline Es-5 7 & 3.07 & 0.93 & 1.59 & 0.33 & 0.16 & 0.00 & 2.08 & 0.75 & 0.18 & 0.93 \\
\hline Es-5 8' & 3.01 & 0.99 & 1.60 & 0.31 & 0.25 & 0.00 & 2.16 & 0.67 & 0.16 & 0.83 \\
\hline \multirow{2}{*}{\multicolumn{11}{|c|}{ Morrón de Totana Unit (2) (analyses corresponding to R4 Ill- }} \\
\hline & & 0.73 & 1.72 & 0.13 & 0.27 & 0.00 & 2.12 & 0.67 & 0.00 & 0.67 \\
\hline Es-77 15 & 3.16 & 0.84 & 1.95 & 0.03 & 0.13 & 0.00 & 2.11 & 0.63 & 0.00 & 0.63 \\
\hline Es-77 16 & 3.28 & 0.72 & 1.82 & 0.10 & 0.15 & 0.00 & 2.07 & 0.68 & 0.00 & 0.68 \\
\hline Es-77 17 & 3.38 & 0.62 & 1.47 & 0.32 & 0.19 & 0.00 & 1.99 & 0.93 & 0.00 & 0.93 \\
\hline Es-86 9 & 3.34 & 0.66 & 1.60 & 0.17 & 0.34 & 0.00 & 2.10 & 0.72 & 0.00 & 0.72 \\
\hline Es-86 10 & 3.57 & 0.43 & 1.51 & 0.12 & 0.46 & 0.00 & 2.09 & 0.65 & 0.00 & 0.65 \\
\hline Es-86 11 & 3.53 & 0.47 & 1.56 & 0.12 & 0.36 & 0.00 & 2.03 & 0.77 & 0.00 & 0.77 \\
\hline Es-86 13 & 3.24 & 0.76 & 1.52 & 0.25 & 0.35 & 0.00 & 2.11 & 0.84 & 0.00 & 0.84 \\
\hline Es-86 14 & 3.24 & 0.76 & 1.73 & 0.13 & 0.19 & 0.00 & 2.05 & 0.84 & 0.00 & 0.84 \\
\hline Es- 952 & 3.23 & 0.77 & 1.58 & 0.16 & 0.19 & 0.04 & 1.98 & 1.03 & 0.00 & 1.03 \\
\hline Es- 955 & 3.36 & 0.64 & 1.69 & 0.13 & 0.25 & 0.00 & 2.07 & 0.70 & 0.00 & 0.70 \\
\hline Es- 956 & 3.36 & 0.64 & 1.48 & 0.27 & 0.33 & 0.00 & 2.09 & 0.78 & 0.00 & 0.78 \\
\hline
\end{tabular}

(1) SEM/EDX analyses; (2) TEM/AEM analyses

selected from each unit. The Yéchar and Los Molinos units are characterized by compositions approaching those of evolved micas, with a sum of interlayer cations slightly less than 1 a.p.f.u., typical of phengite or muscovite rather than authigenic illite. In contrast, the La Santa and Morrón de Totana units show heterogeneous mica compositions and display deficiencies in interlayer cations (Fig. 14a). This last feature is more evident in the Morrón de Totana analyses, where the illitic 

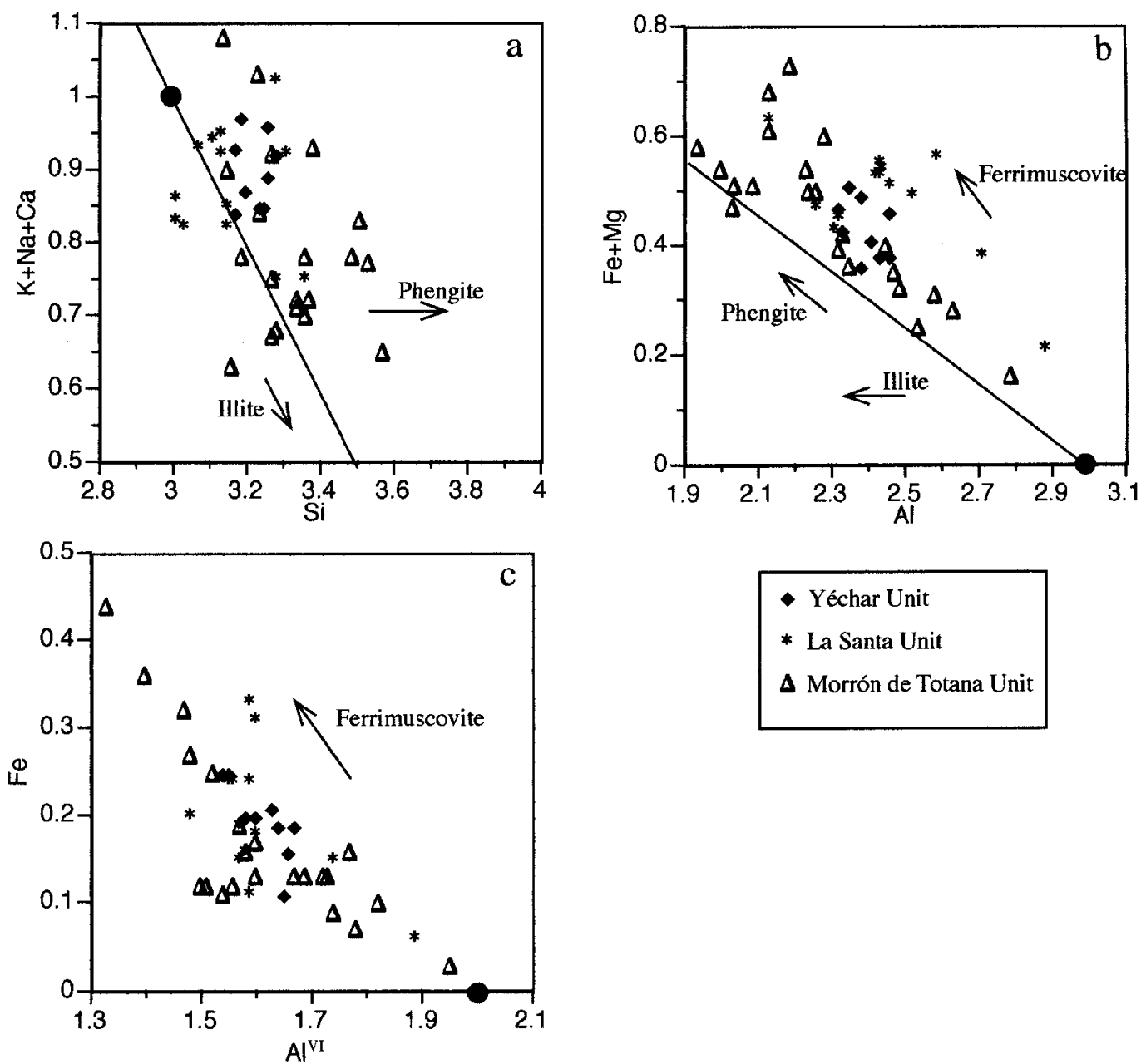

- Yéchar Unit

* La Santa Unit

$\Delta$ Morrón de Totana Unit

FIG. 14. Plots of values of chemical compositions of K-rich, dioctahedral phyllosilicates; solid circles and lines indicate values for theoretical muscovite and corresponding exchange vectors, respectively.

character is consistent with the presence of the R4 mixed-layer illite-smectite described above. Most of the micas are phengitic in composition (Fig. 14a,b), with an $\mathrm{Fe} /(\mathrm{Fe}+\mathrm{Mg})$ ratio that varies over the range $0.2-0.85$. However, the detrital-like grains are similar to those of end-member muscovite (see below, detrital muscovite $v s$. metamorphic muscovite, or Table 5), with much lower $\mathrm{Fe}$ and $\mathrm{Mg}$ contents. Data plotted in Fig. 14b,c confirm the assumption of a significant ferrimuscovitic substitution (Guidotti et al., 1994). Some of the K-mica analysed in the Los Molinos and La Santa units were found to have significant $\mathrm{Na}$ contents (up to 0.2 a.p.f.u.). Although $\mathrm{Ti}$ is unusual in dioctahedral micas, it has been measured in several analyses
( $<0.05$ a.p.f.u.). The most evident feature in the plots is the scattering of data in the La Santa and Morrón de Totana units, i.e. where diagenetic conditions are not exceeded. In contrast, the Yéchar Unit analyses define a narrow field in the diagrams and the Los Molinos data are even closer to the theoretical muscovite composition (Table 3).

Typical compositions of micas intermediate to muscovite and paragonite, called $\mathrm{Na}-\mathrm{K}$ micas in this paper, are shown in Table 4. The compositions are quite variable, even in the same sample. When compared with analyses of K-rich dioctahedral micas (Table 3) and paragonite, analyses are seen to span the entire range from muscovite to paragonite. Some analyses (e.g. Es-5 9) fall within 
TABLE 4. Chemical compositions for Na-K micas normalized to $\mathrm{O}_{10}(\mathrm{OH})_{2}$.

\begin{tabular}{|c|c|c|c|c|c|c|c|c|c|c|c|}
\hline & $\mathrm{Si}$ & ${ }^{\mathrm{IV}} \mathrm{Al}$ & ${ }^{\mathrm{VI}} \mathrm{Al}$ & $\mathrm{Fe}$ & $\mathrm{Mg}$ & $\mathrm{Ti}$ & ${ }^{\mathrm{VI}_{\Sigma}}$ & $\mathrm{Ca}$ & K & $\mathrm{Na}$ & $\Sigma$ inter. \\
\hline Es-5 14 & 3.13 & 0.87 & 1.90 & 0.04 & 0.09 & 0.02 & 2.04 & 0.00 & 0.34 & 0.48 & 0.83 \\
\hline Es-5 15 & 3.21 & 0.79 & 1.76 & 0.09 & 0.37 & 0.00 & 2.22 & 0.00 & 0.15 & 0.38 & 0.53 \\
\hline Es-5 4 & 3.18 & 0.82 & 1.87 & 0.04 & 0.19 & 0.00 & 2.09 & 0.00 & 0.13 & 0.61 & 0.74 \\
\hline Es-5 12 & 3.29 & 0.71 & 1.72 & 0.08 & 0.29 & 0.00 & 2.08 & 0.00 & 0.39 & 0.36 & 0.76 \\
\hline Es-5 13 & 3.23 & 0.77 & 1.79 & 0.05 & 0.28 & 0.00 & 2.12 & 0.00 & 0.29 & 0.41 & 0.69 \\
\hline Es-5 9 & 2.96 & 1.04 & 1.63 & 0.19 & 0.29 & 0.00 & 2.11 & 0.00 & 0.48 & 0.56 & 1.04 \\
\hline Es-5 8 & 2.92 & 1.08 & 1.56 & 0.43 & 0.08 & 0.01 & 2.09 & 0.03 & 0.14 & 0.80 & 0.96 \\
\hline
\end{tabular}

the limits of the solvus between muscovite and paragonite, the limbs of that solvus having the approximate compositions $\mathrm{ms}_{60} \mathrm{pg}_{40}$ and $\mathrm{ms}_{20} \mathrm{pg}_{80}$ (Li et al., 1994a).

Detrital muscovite vs. metamorphic muscovite. Detrital-like micas of sample Es-95, the lowestgrade one, are large enough to be analysed (Table 5) by electron microprobe (EMPA). These data have been compared with the AEM data of other samples. Compositions of detrital-like grains of the lowest-grade sample and the detrital micas of the anchizonal-grade sample, Es-53 (Fig. 15), are very similar, and close to that of end-member muscovite. These data suggest that the detrital mica has a common source for the different units that comprise Sierra Espuña. Figure 15 also compares the data from authigenic micas of the same samples, which are clearly more phengitic ( $\mathrm{Fe}+\mathrm{Mg}$ $=0.15-0.75$ a.p.f.u. $)$ than the detrital ones $(\mathrm{Fe}+\mathrm{Mg}$ $=0.1-0.2$ a.p.f.u.).

Chlorite. Trioctahedral and di-trioctahedral (sudoite) chlorites have been analysed (Table 6). The former, corresponding to the species clinochlore, is common in most of the samples, unlike sudoite, which is absent from most (Table 1). Sudoite was identified because the sum of octahedral cations is nearly equal to 5 a.p.f.u. and the $\mathrm{Si}$ and $\mathrm{Al}$ contents are higher than in trioctahedral chlorite (Fig. 16a). A slight contamination by interlayer cations ( $\mathrm{K}$ and $\mathrm{Na}$ ) has been detected; therefore, the formulae were recalculated in order to eliminate those impurities (see Analytical Methods). Although total $\mathrm{Fe}$ has been considered as $\mathrm{Fe}^{2+}$, according to Fransolet \& Bourguignon (1978) the $\mathrm{Fe}^{3+}$ content in sudoite may be greater than the $\mathrm{Fe}^{2+}$ content. As several analyses have an octahedral sum slightly higher than the ideal value of 5 a.p.f.u., this may indicate a trioctahedral substitution and/or the presence of significant $\mathrm{Fe}^{3+}$. No Ti or Mn were detected. The
$\mathrm{Fe} /(\mathrm{Fe}+\mathrm{Mg})$ ratios do not define a clear trend throughout the sequence (Fig. 16b); nevertheless, it is much greater in chlorite in the Morrón de Totana analyses, falling in the characteristic range of diagenetic chlorites ( $\mathrm{Li}$ et al., 1994b). There is an increase in $\mathrm{Mg}$ content (from 1.5 to 4 a.p.f.u.) concomitant with increase in grade, as compatible with some other sequences (e.g. Bevins et al., 1991).

\section{DISCUSSION}

\section{Dioctahedral phyllosilicates: chemical compositions, IC values and polytypes}

On the basis of their large size, homogeneity of individual grains, and well-crystallized aspect, detrital dioctahedral mica grains were identified in several samples, with the exception of those of greenschist facies. This confirms the idea of the

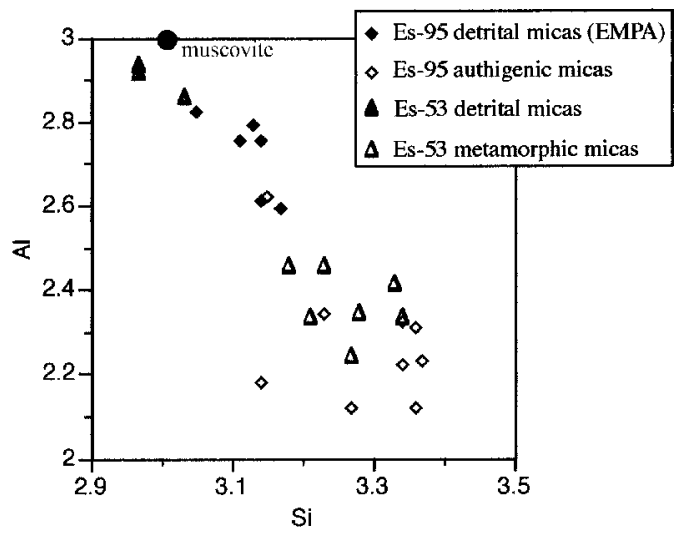

FIG. 15. Plot of $\mathrm{Si}$ vs. Al contents of detrital and authigenic micas of samples Es-95 and Es-53. Solid symbols $=$ detrital micas, open symbols $=$ authigenic micas. 
TABLE 5. EMPA data for detrital-like crystals of mica normalized to $\mathrm{O}_{10}(\mathrm{OH})_{2}$.

\begin{tabular}{lccccccccccc}
\hline & $\mathrm{Si}$ & ${ }^{\mathrm{IV}} \mathrm{Al}$ & ${ }^{\mathrm{VI}} \mathrm{Al}$ & $\mathrm{Fe}$ & $\mathrm{Mg}$ & $\mathrm{Ti}$ & ${ }^{\mathrm{VI}_{\Sigma}}$ & $\mathrm{Ca}$ & $\mathrm{K}$ & $\mathrm{Na}$ & $\mathrm{K}+\mathrm{Na}+\mathrm{Ca}$ \\
\hline Es-95,z1,1 & 3.13 & 0.87 & 1.93 & 0.05 & 0.04 & 0.01 & 2.03 & 0.00 & 0.65 & 0.22 & 0.87 \\
Es-95,z1,1 & 3.14 & 0.86 & 1.90 & 0.06 & 0.07 & 0.01 & 2.04 & 0.00 & 0.68 & 0.19 & 0.87 \\
Es-95,z1, 2 & 3.14 & 0.86 & 1.91 & 0.05 & 0.09 & 0.01 & 2.06 & 0.00 & 0.70 & 0.06 & 0.77 \\
Es-95,z2, 1 & 3.14 & 0.86 & 1.76 & 0.12 & 0.10 & 0.03 & 2.01 & 0.02 & 0.95 & 0.04 & 1.01 \\
Es-95,z2, 2 & 3.17 & 0.83 & 1.77 & 0.12 & 0.11 & 0.03 & 2.02 & 0.00 & 0.95 & 0.04 & 0.99 \\
Es-95,z4, 1 & 3.05 & 0.95 & 1.88 & 0.05 & 0.07 & 0.04 & 2.04 & 0.00 & 0.81 & 0.09 & 0.89 \\
Es-95,z4, 2 & 3.11 & 0.89 & 1.87 & 0.06 & 0.07 & 0.04 & 2.04 & 0.00 & 0.78 & 0.09 & 0.86 \\
& & & & & & & & & & & \\
\hline
\end{tabular}

relative stability of muscovite in most diagenetic environments (Crowley, 1991). The compositions of the detrital grains of samples from different units are similar. The lack of heterogeneity which is expected for mica from a complex source implies a common source area for all samples.
The IC values define a trend from diagenetic to anchizonal conditions, but with smaller IC values in bulk-rock fractions, consistent with the contribution of detrital mica. The coexistence of mature mica with lower-grade I-S or illite in the sub-greenschist facies rocks shows that those rocks have not

TABLE 6. Representative chemical compositions for chlorite normalized to $\mathrm{O}_{10}(\mathrm{OH})_{8}$.

\begin{tabular}{|c|c|c|c|c|c|c|c|}
\hline & $\mathrm{Si}$ & ${ }^{\mathrm{IV}} \mathrm{Al}$ & ${ }^{\mathrm{VI}} \mathrm{Al}$ & $\mathrm{Fe}$ & $\mathrm{Mg}$ & ${ }^{\mathrm{V}_{\Sigma}}$ & $\mathrm{Fe} / \mathrm{Fe}+\mathrm{Mg}$ \\
\hline \multicolumn{8}{|c|}{ Yéchar Unit } \\
\hline Es53-1 & 2.73 & 1.27 & 1.12 & 1.21 & 3.76 & 6.09 & 0.24 \\
\hline Es53-4 & 2.87 & 1.13 & 1.25 & 0.70 & 4.00 & 5.96 & 0.15 \\
\hline Es53-12 & 3.03 & 0.97 & 1.30 & 1.46 & 3.07 & 5.83 & 0.32 \\
\hline Es53-13 & 2.77 & 1.23 & 1.25 & 1.22 & 3.54 & 6.01 & 0.26 \\
\hline Es53-15 & 3.07 & 0.93 & 1.46 & 0.94 & 3.23 & 5.64 & 0.23 \\
\hline Es53-42 & 2.71 & 1.29 & 1.52 & 1.60 & 2.94 & 6.06 & 0.35 \\
\hline \multicolumn{8}{|c|}{ La Santa Unit } \\
\hline Es2-4 & 3.19 & 0.81 & 1.47 & 1.48 & 2.73 & 5.69 & 0.35 \\
\hline Es2-5* & 3.65 & 0.35 & 1.83 & 1.18 & 2.25 & 5.26 & 0.34 \\
\hline Es5-1* & 3.54 & 0.46 & 2.93 & 0.23 & 1.72 & 4.88 & 0.12 \\
\hline Es5-5* & 3.61 & 0.39 & 2.92 & 0.21 & 1.78 & 4.90 & 0.10 \\
\hline Es5-10* & 3.09 & 0.91 & 2.62 & 0.28 & 2.21 & 5.11 & 0.11 \\
\hline Es5-16 & 3.10 & 0.90 & 1.97 & 1.12 & 2.34 & 5.43 & 0.32 \\
\hline Es5-17* & 3.50 & 0.50 & 2.52 & 0.76 & 1.70 & 4.99 & 0.31 \\
\hline Es-5 10’* & 3.64 & 0.36 & 2.13 & 0.97 & 2.02 & 5.12 & 0.32 \\
\hline Es-5 11 & 2.91 & 1.09 & 1.43 & 1.36 & 3.14 & 5.93 & 0.30 \\
\hline Es-5 12* & 3.82 & 0.18 & 2.29 & 0.87 & 1.79 & 4.95 & 0.33 \\
\hline Es-5 13* & 3.16 & 0.84 & 3.02 & 0.21 & 1.72 & 4.94 & 0.11 \\
\hline Es-5 16'* & 3.46 & 0.54 & 3.41 & 0.13 & 1.01 & 4.55 & 0.11 \\
\hline Es-5 17'* & 3.00 & 1.00 & 2.82 & 0.33 & 1.94 & 5.09 & 0.14 \\
\hline Es-5 18* & 2.85 & 1.15 & 2.85 & 0.26 & 2.04 & 5.15 & 0.11 \\
\hline \multicolumn{8}{|c|}{ Morrón de Totana Unit } \\
\hline Es-86 2* & 3.77 & 0.23 & 2.53 & 0.88 & 1.49 & 4.90 & 0.37 \\
\hline Es-86 4 & 2.84 & 1.16 & 1.66 & 2.30 & 1.81 & 5.78 & 0.56 \\
\hline Es-86 5* & 3.50 & 0.50 & 1.91 & 1.92 & 1.51 & 5.34 & 0.56 \\
\hline Es-86 6* & 3.66 & 0.34 & 1.89 & 1.91 & 1.49 & 5.29 & 0.56 \\
\hline Es-86 7 & 3.15 & 0.85 & 1.29 & 2.73 & 1.76 & 5.78 & 0.61 \\
\hline
\end{tabular}

* indicates sudoite analyses 

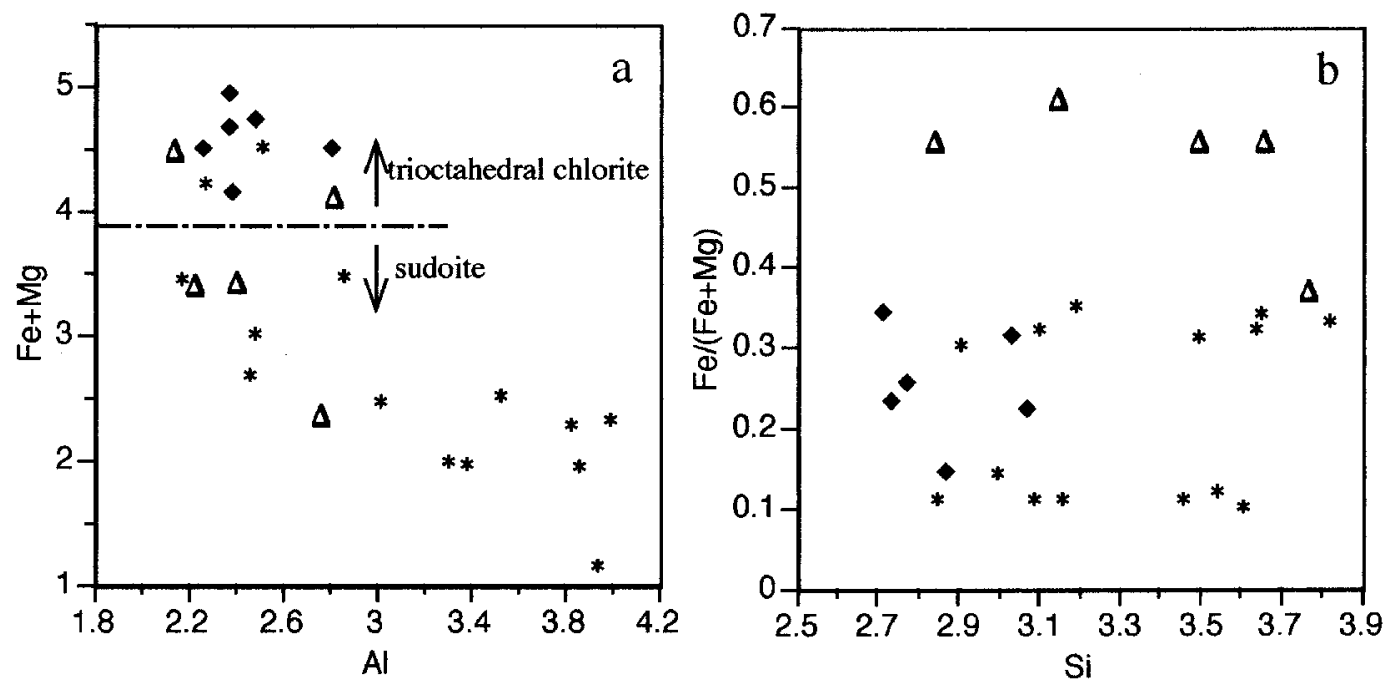

Yéchar Unit * La Santa Unit $\Delta$ Morrón de Totana Unit

FIG. 16. (a) Plot of $\mathrm{Al} v s$. Fe+Mg contents of chlorites, illustrating the contrast in composition between tritrioctahedral clinochlore or chamosite and di-trioctahedral sudoite; (b) plot of $\mathrm{Si} v s$. $\mathrm{Fe} /(\mathrm{Fe}+\mathrm{Mg})$ ratio of chlorites, showing an absence of compositional trends throughout the sampled sequence.

reached stable chemical or textural equilibrium, at least at the $\mu \mathrm{m}$ scale. In addition, the lack of chemical equilibrium among diagenetic I-S and illite at the nm scale is demonstrated by their highly variable $\mathrm{Fe}+\mathrm{Mg}$ contents (0.06-0.75 a.p.f.u.). The averages of the sum of interlayer cations are close to 1 a.p.f.u. in the Los Molinos and Yéchar units, as consistent with mica, but values of 0.6 a.p.f.u. corresponding to I-S or illitic compositions are also present in the Morrón de Totana Unit. Except for samples Es-102 and Es-53, the variable compositions represent a metastable state, with compositions of micas determined by a combination of phengitic, ferrimuscovitic and illitic vectors, as shown by Fig. 14a,b.

Paragonite is generally considered an index mineral for the anchizone (Frey, 1987), but Li et al. (1994a) have shown that paragonite coexists with K-rich mica in grades as low as that of the late diagenetic zone for a prograde sequence. Samples in which muscovite, paragonite and intermediate Na-K mica coexist, as in sample Es-5, are consistent with metastability, both because more than two such micas coexist and because their compositions are incompatible with the solvus in the muscovite-paragonite system (see below). While the $2 M$ polytype, typical of metamorphic micas, is the most common in these samples, the $1 M_{d}$ polytype also occurs in some diagenetic samples particularly those from the Morrón de Totana Unit. The $1 M_{d}$ polytype is metastable relative to the $2 M$ polytype, and the coexistence of both polytypes further demonstrates a lack of equilibrium at the nm scale. Dong \& Peacor (1996) showed that the disorder noted in the diagenetic phyllosilicates by SAED is a consequence of the general high entropy of phases formed at very low temperatures that produces, for example, stacking defects separating packets with no more than 10 layers. These packets progressively thicken with increasing metamorphic grade, and the $2 M$ polytype then becomes the most common polytype in authigenic micas. The nm-scale size of the lower-grade clays, and the regular increase in size with increasing grade, reflect the lack of textural equilibrium in the lowgrade samples.

A wide range of sample characteristics thus imply that the lower-grade samples are in states of metastable equilibrium, those factors including coexistence of mature mica with I-S and illite, variable chemical compositions, incompatible compositions of white micas, small crystal sizes, defect-rich states, and polytypism. Such data emphasize the notion of 'reaction progress' relative 
to Ostwald-step rule processes, metastable dioctahedral clay systems undergoing reactions toward the state of stable chemical and textural equilibrium approached in greenschist-facies samples (Essene \& Peacor, 1995).

\section{Prograde evolution based on TEM data: correlation with the Basque-Cantabrian sequence (Northern Spain)}

With increasing grade, TEM data confirm that crystal thickness increases, crystal defect density decreases, compositions become less variable and microtextural relations are simpler (e.g. Peacor, 1992). This trend is consistent with three wellcharacterized, low-grade settings: the Gulf Coast sequence (Ahn \& Peacor, 1986) and the Welsh Basin (Merriman et al., 1990), both extensional basins, and the Helvetic Alps (Livi et al., 1997). The latter is a fold-and-thrust belt with similar series of prograde transitions to those observed in Sierra Espuña, in which pelites have passed through a sequence of metastable states in the lithological sequence mudstone and shale, slate and phyllite.

The mudstones of the Morrón de Totana Unit are characterized by the presence of illite-smectite R4 mixed-layers, mica packets of no more than 10-40 layers and the occurrence of $1 M_{d}$ polytypism. The La Santa Unit samples represent a step in the prograde evolution with thicker packets than in the previous samples $(200-700 \AA)$, illitic or phengitic compositions, the absence of illite-smectite mixed layers, as well as the presence of discrete intermediate Na-K micas and paragonite. Although there is a tendency towards non-preferred orientation of crystals, it is not so evident as in the Morrón de Totana samples. In the Yéchar Unit (anchizone) and, more clearly, in the Los Molinos phyllites (greenschist facies), the microtextural relations are less complex, the compositions are less variable with phengite and trioctahedral chlorite, crystal thickness are greater $(>400 \AA$ in the Yéchar Unit and $>1000 \AA$ in the Los Molinos Unit), with the packets being defect-free and with a very crystalline aspect. This description has features in common with the three well-characterized low-grade settings previously noted. Only the mineral assemblages vary somewhat, presumably as a function of the differences in bulk-rock composition.

A detailed comparison with the BasqueCantabrian Basin (N Spain) shows that the lowestgrade conditions of Sierra Espuña overlap most of those of that sequence, which is characterized by passive burial diagenesis ( $8000 \mathrm{~m}$ thick) (Nieto et al., 1996). Only in the deepest sample of the Basque-Cantabrian sequence is illite-smectite mixed layering absent. Figure 12 of this study is very similar to Fig. 7 in Nieto et al. (1996), and both images correspond to diagenetic samples from different settings; nevertheless, they illustrate similar mica packets $100-200 \AA$ thick with parallel-to-subparallel boundaries, the orientation of which is inferred to represent bedding. Therefore, there is a parallelism between these sequences down to the scale of individual claymineral grains, even though they developed under different conditions, with stress presumably playing a significant role in the Sierra Espuña units. The texture of the least metamorphosed sample (Fig. 13) is reminiscent of the typical textural relations of smectite described by Nieto et al. (1996) (see Fig. 4). Although it corresponds to illite-rich interstratified illite-smectite, the clay mineral grains conserved the grain size and anastomosing, discontinuous array of original smectite layers.

Despite the similarities between the two sequences, the chemical behaviour of the micas are clearly different since the grade corresponding to the phengitic compositions of the Yéchar Unit is not reached in the Basque-Cantabrian Basin, where the deepest and highest-grade sample has illitic compositions equivalent to those of the La Santa Unit. That is, in a passive burial metamorphic context as in the Basque-Cantabrian Basin, the factors responsible for increasing the rate of chemical reactions are less significant than in the sequences that were affected by tectonic stress. Tectonic stress introduces defects which in turn increases the rate of dissolution of strained grains, thus increasing the rate of dissolution-crystallization reactions typical of clay minerals. Perhaps more importantly, regional tectonic stress is known to cause mobilization of fluids (e.g. Oliver, 1986). The presence and activity of such fluids is a prime cause of increased rates of dissolution, ion diffusion and crystallization. Tectonic activity thus may have a two-fold effect in increasing rate of clay-mineral reactions. The phengite component may in part be a measure of the reaction progress, depending on the reaction kinetics in very low-grade rocks. According to Merriman \& Peacor (1999), where heat flow is low, as in accretionary settings, phengite contents are typically high, perhaps because there is insufficient thermal energy to 
cause equilibration of the phengite component of neoformed illite by contrast with extensional basins where this component is typically small.

\section{Coexistence of trioctahedral chlorite and sudoite. Implications for multiple metamorphic events}

In metamorphic rocks the coexistence of minerals that formed at different times and conditions on a PTt path, i.e. not in equilibrium, is a commonly observed feature where the metamorphic history is complex. Gross differences in the grain size of coexisting phases has long been recognized by metamorphic petrologists as an indicator of nonequilibrium mineral assemblages. Historically, much less attention has been paid to such relations in subgreenschist-facies rocks because prior to the introduction of SEM+TEM techniques their small grain size prevented observations of textural relations. Study of such rocks, e.g. by XRD, provides little information on textural relations beyond determination of degree of preferred orientation.

Study by XRD of the samples showed that sudoite and trioctahedral chlorite coexist. If they had formed at the same time and under the same $P-T$ conditions, their compositions would define the limbs of a solvus. The TEM images show, however, that wherever they are in contact, the sudoite transects the packets of trioctahedral chlorite (e.g. Fig. 8). Furthermore, as illustrated in Fig. 8, the trioctahedral chlorite is commonly deformed and displays strain contrast in TEM images. These textural relations suggest that sudoite was introduced subsequent to the formation of trioctahedral chlorite. Similar observations were made by Giorgetti et al. (1998), who concluded that textures in Verrucano metasediments showed that sudoite post-dated chloritoid, pyrophyllite and trioctahedral chlorite; i.e. sudoite is in disequilibrium with the latter minerals and formed as a retrograde phase. In rocks of the Sierra Espuña area, differences in bulkrock composition are small (Table 2) and do not correspond to the presence or absence of sudoite (Table 1), i.e. the random occurrence of sudoite, independent of bulk-rock composition, is compatible with a lack of equilibrium relations. These relations collectively imply that sudoite was introduced at some time subsequent to the formation of mineral assemblages at peak metamorphic conditions. On the other hand, the size of sudoite packets is similar to that of trioctahedral chlorite, as consistent with formation at conditions not much different from those for chlorite.

In samples from the Morrón de Totana, both sudoite and trioctahedral chlorite were affected by retrograde alteration to smectite. The TEM images show sudoite (Fig. 11) and trioctahedral chlorite (Fig. 10) with interstratified layers of smectite with spacings of $10 \AA$ due to collapse and dehydration in the TEM environment, and even packets of smectite $150 \AA$ A thick within chlorite crystals. These relations imply that both sudoite and trioctahedral chlorite have been affected by retrograde alteration at the very low temperatures consistent with smectite formation, although the presence of more subtle alteration features in sudoite of some samples suggests that it was less susceptible to alteration.

We therefore conclude that at least three episodes of phyllosilicate formation can be recognized in rocks from the Sierra Espuña-area. Trioctahedral chlorite was presumably produced at the highest metamorphic/diagenetic grade in equilibrium with paragonite and phengite. Subsequently, sudoite was introduced, but at $P-T$ conditions which could not have been much different than those of peak metamorphic grade. Finally, at very low- $T$ conditions, hydrothermal fluids caused partial alteration of trioctahedral chlorite and sudoite to smectite.

Retrograde products formed by the reaction of fluids with mineral phases generated during an earlier, prograde event, were described previously by Nieto et al. (1994) and Zhao et al. (1999). Those reactions occurred on a regional scale, but similar reactions have been observed on a more localized scale. The fluid activity associated with a major fault zone is a common source for these reactions (e.g. Jiang et al., 1990). The structure of Sierra Espuña (Fig. 1) is based on imbrication processes that superimpose units that have subsequently been affected by faults and folds and that have undergone significant uplift, at least $800 \mathrm{~m}$, from the late Miocene to the present (Sanz de Galdeano et al., 2001). Given this evolution, it is easy to justify the retrograde processes that usually seem to be related with tectonic events during which fluid flow and fluid/rock ratios are enhanced (Merriman \& Peacor, 1999). Moreover, according to Nieto et al. (1994), the uplift of the Betic Cordillera would furnish the introduction of phreatic water into the system, producing a reactive environment adequate for the genesis of smectite. Geological conditions are therefore consistent with post-peak metamorphic conditions as implied by the TEM observations. 
The introduction of sudoite as a major phase during metamorphism implies the possibility of additional overprints on a simple prograde assemblage, the evidence for which might be subtle. The Na-rich micas at all grades have compositions which either fall within the solvus or are too $\mathrm{Na}$ rich to correspond to the limb of the solvus. In the highest-grade rocks, such micas coexist with muscovite. Those relations are incompatible with chemical equilibrium, despite the fact that relations for muscovite and other minerals imply an approach to chemical equilibrium. Furthermore, there is a close association of Na-rich micas with sudoite (e.g. Fig. 7). Those relations imply the possibility that Na-micas were introduced concomitant with sudoite. P. Mata (pers. comm.) has shown, for example, that overprinting of an epizonal assemblage by hydrothermal solutions resulted in the introduction of both an Al-rich variety of chlorite (cookeite) and paragonite in pelites of the Cameros Basin, Spain. The textural relations such as crosscutting textures, which are so striking for sudoite, were not observed for Na-rich micas. Nevertheless, the possibility of such overprinting must be considered.

In spite of all these prograde-retrograde processes, in the Los Molinos Unit a small number of homogeneous phases coexist in chemical equilibrium and the fine-grained, metamorphic phyllosilicates are clearly parallel to cleavage with a typical metamorphic aspect. Finally, all the textural and compositional changes that have operated in the Espuña area during the metamorphic evolution proceed toward a simpler system representing both textural and chemical equilibrium, which is characteristic of greenschist-facies conditions.

\section{Roles of detrital and authigenic phyllosilicates during slaty cleavage development}

Van der Pluijm et al. (1998) focused on the respective roles of the phyllosilicates of detrital origin and those formed during diagenesis and metamorphism and observed that detrital phyllosilicates remain preferentially oriented parallel to bedding in pelites with slaty cleavage, whereas finegrained, metamorphic phyllosilicates are oriented parallel to cleavage.

Although it is usually difficult to determine the preferred orientations of phyllosilicates in TEM images, as the grade increases, better-aligned packets occur in the cleavage orientation. The texture of the least metamorphosed sample, in which even incipient slaty cleavage is absent, is reminiscent of the typical textural relation of smectites described in the literature. The illitesmectite mixed-layers conserve the textural features of possible previous smectite, such as anastomosing fringes, curved and discontinuous, with variations in interplanar spacing, $d_{001}$. These features indicate that the minimum energy conditions to initiate mechanical transformations have not been reached in the lower-grade samples, as postulated by Ho et al. (1996), since slaty cleavage develops as a result of interactive mechanical deformation and thermally driven, dissolution and crystallization processes (Knipe, 1981). In contrast, in the Los Molinos Unit, large crystals of chlorite and white mica (>1000 $\AA$ ) occur which are of metamorphic origin, but with no detrital grains (Fig. 3a). Phyllosilicates are preferentially oriented parallel to slaty cleavage, in response to increased temperature and tectonic strain (Merriman \& Peacor, 1999). The oriented microfabrics and slaty cleavage, well developed in the rocks of this unit, must be a product of a higher thermal and strain energy environment reached in the deepest part of the sequence. As pointed out by Van der Pluijm et al. (1998), a continuous range of orientations is evidence for mechanical rotation of grains, whereas the lack of such transitional orientations implies that cleavage-parallel phyllosilicates originated through dissolution of bedding-paralle and crystallization in the slaty cleavage orientation. As observed in this study for the Intermediate Units, grains with orientations which are transitional from bedding-parallel to slaty cleavage orientation are only rarely observed. Cleavage formation is therefore inferred to have occurred entirely, or nearly entirely through dissolution and crystallization.

\section{ACKNOWLEDGMENTS}

We thank M.M. Abad Ortega from the Centro de Instrumentación Científica of the Universidad de Granada for her help with HRTEM and I. Nieto for her essential help with sample preparation. Financial support was supplied by Research Project $\mathrm{n}^{\circ}$ BT 20000582, FPI research grant to I.A., both of the Spanish Ministry of Science and Technology, Research Group RNM-0179 of the Junta de Andalucía and to D.R.P. by NSF grant EAR-9814391. 


\section{REFERENCES}

Ahn J.H. \& Peacor D.R. (1986) Transmission and analytical electron microscopy of the smectite-toillite transition. Clays and Clay Minerals, 34, $165-179$.

Azañón J.M. \& Crespo-Blanc A. (2000) Exhumation during a continental collision inferred from the tectonometamorphic evolution of the Alpujarride Complex in the central Betics (Alborán Domain, SE Spain). Tectonics, 19, 549-565.

Bevins R.E., Robinson D. \& Rowbotham G. (1991) Compositional variations in mafic phyllosilicates from regional low-grade metabasites and application of the chlorite geothermometer. Journal of Metamorphic Geology, 9, 711-721.

Cliff G. \& Lorimer G.W. (1975) The quantitative analysis of thin specimens. Journal of Microscopy, 103, 203-207.

Crowley S.F. (1991) Diagenetic modification of detrital muscovite: an example from the Great Limestone Cyclothem (Carboniferous) of Co. Durham, UK. Clay Minerals, 26, $91-103$.

Dong H. \& Peacor D.R. (1996) TEM observations of coherent stacking relations in smectite and illite of shales: evidence for MacEwan crystallites and dominance of $2 \mathrm{M}_{1}$ polytypes. Clays and Clay Minerals, 44, $257-275$.

Essene E. \& Peacor D.R. (1995) Clay mineral thermometry: a critical perspective. Clays and Clay Minerals, 43, 540-553.

Fransolet A.M. \& Bourguignon P. (1978) Dioctahedral chlorite in quartz veins from Ardennes, Belgium. The Canadian Mineralogist, 16, 365-373.

Fransolet A.M. \& Schreyer W. (1984) Sudoite, di/ trioctahedral chlorite: a stable low-temperature phase in the system $\mathrm{MgO}-\mathrm{Al}_{2} \mathrm{O}_{3}-\mathrm{SiO}_{2}-\mathrm{H}_{2} \mathrm{O}$. Contributions to Mineralogy and Petrology, 86, 409-417.

Frey M. (1987) Very low-grade metamorphism of clastic sedimentary rocks. Pp. 9-58 in: Low Temperature Metamorphism (M. Frey, editor). Blackie, Glasgow, UK.

Giorgetti G., Goffé B., Memmi I. \& Nieto F. (1998) Metamorphic evolution of Verrucano metasediments in northern Apennines: new petrological constraints. European Journal of Mineralogy, 10, $1295-1308$.

Guidotti C.V. \& Sassi F.P. (1986) Classification and correlation of metamorphic facies series by means of muscovite $\mathrm{b}_{0}$ data from low grade metapelites. Neues Jahrbuch für Mineralogie Abhandlungen, 153, $363-380$.

Guidotti C.V., Yates M.G., Dyar M.D. \& Taylor M.E. (1994) Petrogenetic implications of the $\mathrm{Fe}^{3+}$ content of muscovite in pelitic schists. American Mineralogist, 79, $793-795$.

Guthrie G.D. \& Veblen D.R. (1989) High resolution electron microscopy of mixed-layer illite/smectite:
Computer simulations. Clays and Clay Minerals, 37, $1-11$.

Ho N. Peacor D.R. \& Van der Pluijm B.A. (1996) Contrasting roles of detrital and authigenic phyllosilicates during slaty cleavage development. Journal of Structural Geology, 18, 615-623.

Jiang W.T., Peacor D.R., Merriman R.J. \& Roberts, B. (1990) Transmission and analytical electron microscopic study of mixed layer illite/smectite formed as an apparent replacement product of diagenetic illite. Clays and Clay Minerals, 38, 449-468.

Jiang W.T., Peacor D.R. \& Buseck P.R. (1994) Chlorite geothermometry? Contamination and apparent octahedral vacancies. Clays and Clay Minerals, 42, $593-605$.

Kisch H.J. (1991) Development of slaty cleavage and degree of very-low-grade metamorphism: a review. Journal of Metamorphic Geology, 9, 735-750.

Knipe J.R. (1981) The interaction of deformation and metamorphism in slates. Tectonophysics, 78, $249-272$.

Kretz R. (1983) Symbols for rock-forming minerals. American Mineralogist, 68, $277-279$.

Li G., Peacor D.R., Merriman R.J. \& Roberts B. (1994a) The diagenetic to low grade metamorphism evolution of matrix white mica in the system muscoviteparagonite in a mudrock from Central Wales, UK. Clays and Clay Minerals, 42, 369-381.

Li G., Peacor D.R., Merriman R.J., Roberts B. \& Van der Pluijm B.A. (1994b) TEM and AEM constraints on the origin and significance of chlorite-mica stacks in slates: an example from Central Wales, U.K. Journal of Structural Geology, 16, 1139-1157.

Livi K.J.T., Veblen D.R., Ferry J.M. \& Frey M. (1997) Evolution of 2:1 layered silicates in low-grade metamorphosed Liassic shales of Central Switzerland. Journal of Metamorphic Geology, 15, $323-344$.

Lonergan L. (1991) Structural evolution of the Sierra Espuña, Betic Cordillera, SE Spain. PhD thesis, Oxford University, UK.

Lonergan L., Platt J.P. \& Gallagher L. (1994) The Internal-External Zone Boundary in the eastern Betic Cordillera, SE Spain. Journal of Structural Geology, 16, $175-188$.

Mäkel G.H. (1981) Differences in tectonic evolution of superimposed Maláguide and Alpujárride tectonic units in the Espuña area (Betic Cordilleras, Spain). Geology in Mijnbouw, 60, 203-208.

Mäkel G.H. (1985) The geology of the Maláguide Complex and its bearing on the geodynamic evolution of the Betic-Rif orogen (southern Spain and northern Morocco). GUA papers of Geology. Ser 1, 22, 263 pp.

Mäkel G.H. \& Rondeel H.E. (1979) Differences in stratigraphy and metamorphism between superposed Maláguide and Alpujárride units in the Espuña area 
(Betic Cordilleras, Spain). Estudios Geológicos, 35, $109-117$.

Martín-Martín M. \& Martín-Algarra A. (1997) La estructura del área de Sierra Espuña (Contacto Zonas Internas-Externas, Sector oriental de la Cordillera Bética). Estudios Geológicos, 53, $237-248$.

Merriman R.J. \& Peacor D.R. (1999) Very low-grade metapelites: mineralogy, microfabrics and measuring reaction progress. Pp. 10-60 in: Low-Grade Metamorphism (M. Frey \& D. Robinson, editors). Blackwell Science, Oxford, UK.

Merriman R.J. \& Roberts B. (1985) A survey of white mica crystallinity and polytypes in pelitic rocks of Snowdonia and Llyn, North Wales. Mineralogical Magazine, 49, $305-319$.

Merriman R.J., Roberts B. \& Peacor D.R. (1990) A transmission electron microscope study of white mica crystallite size distribution in a mudstone to slate transitional sequence, North Wales, UK. Contributions to Mineralogy and Petrology, 106, $27-40$.

Nieto F. (1997) Chemical composition of metapelitic chlorites: X-ray diffraction and optical property approach. European Journal of Mineralogy, 9, $829-841$.

Nieto F., Velilla N., Peacor D.R. \& Ortega-Huertas M. (1994) Regional retrograde alteration of sub-greenschist facies chlorite to smectite. Contributions to Mineralogy and Petrology, 115, 243-252.

Nieto F., Ortega-Huertas M., Peacor D.R. \& Arostegui J. (1996) Evolution of illite/smectite from early diagenesis through incipient metamorphism in sediments of the Basque-Cantabrian Basin. Clays and Clay Minerals, 44, $304-323$.

Oliver J. (1986) Fluids expelled tectonically from orogenic belts: their role in hydrocarbon migration and other geologic phenomena. Geology, 14, $99-102$.

Paquet J. (1969) Étude géologique de l'Ouest de la province de Murcie. Bulletin de la Societé geologique de France, 111, 270 pp.

Peacor D.R. (1992) Diagenesis and low-grade metamorphism of shales and slates. Pp. 113-140 in: Minerals and Reactions at the Atomic Scale: Transmission Electron Microscopy (P.R. Buseck, editor). Reviews in Mineralogy, 27, Mineralogical Society of America, Washington, D.C.

Pouchou, J.L. \& Pichoir, F (1985) 'PAP' (f) (r) (t) procedure for improved quantitative microanalysis. Pp. 104-106 in: Microbeam Analysis (J.T. Armstrong, editor). San Francisco Press, San Francisco, California, USA.

Sanz de Galdeano C., Martín-Martín M. \& Estévez A. (2001) Unidades tectónicas y estructura del sector meridional de Sierra Espuña (Cordillera Bética, Murcia). Estudios Geológicos, 56, 269-278.

Taylor S.R. \& McLennan S.M. (1985) The Continental Crust: its Composition and Evolution. Blackwell, Oxford, UK, 312 pp.

Van der Pluijm B.A., Ho N.C., Peacor D.R. \& Merriman R.J. (1998) Contradictions of slate formation resolved? Nature, 392, 348.

Warr L.N. \& Rice H.N. (1994) Interlaboratory standardization and calibration of clay mineral crystallinity and crystallite size data. Journal of Metamorphic Geology, 12, $141-152$.

Zhao G., Peacor D.R. \& McDowell S.D. (1999) 'Retrograde diagenesis' of clay minerals in the Precambrian Freda sandstone, Wisconsin. Clays and Clay Minerals, 47, 119-130. 